$13{ }^{1}$ National Oceanography Centre, Southampton, Univ. Southampton, European Way, Southampton SO14 3ZH, UK

14

15

16

\title{
Cenozoic evolution of the eastern Black Sea: a test of depth-dependent stretching models
}

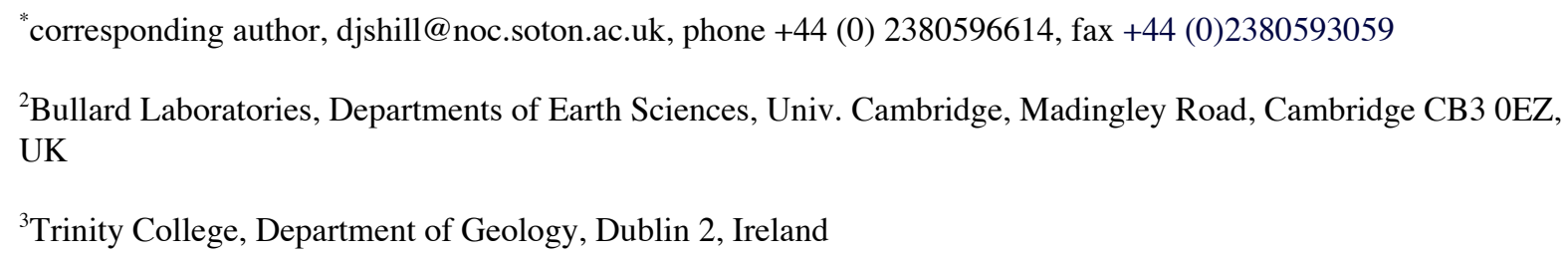




\section{Abstract}

25 Subsidence analysis of the eastern Black Sea basin suggests that the stratigraphy of this

26 deep, extensional basin can be explained by a predominantly pure-shear stretching history. A

27 strain-rate inversion method that assumes pure-shear extension obtains good fits between

28 observed and predicted stratigraphy. A relatively pure-shear strain distribution is also obtained

29 when a strain-rate inversion algorithm is applied that allows extension to vary with depth without

30 assuming its existence or form. The timing of opening of the eastern Black Sea, which occupied

31 a back-arc position during the closure of the Tethys Ocean, has also been a subject of intense

32 debate; competing theories called for basin opening during the Jurassic, Cretaceous or

33 Paleocene/Eocene. Our work suggests that extension likely continued into the early Cenozoic, in

34 agreement with stratigraphic relationships onshore and with estimates for the timing of arc

35 magmatism. Further basin deepening also appears to have occurred in the last $\sim 20$ m.y. This

36 anomalous subsidence event is focused in the northern part of the basin and reaches its peak at

$37 \sim 15-10 \mathrm{Ma}$. We suggest that this comparatively localized shortening is associated with the

38 northward movement of the Arabian plate. We also explore the effects of paleowater depth and

39 elastic thickness on the results. These parameters are controversial, particularly for deep-water

40 basins and margins, but their estimation is a necessary step in any analysis of the tectonic

41 subsidence record stored in stratigraphy.

42

43

44 Keywords: Black Sea, extension, subsidence, strain rate 


\section{Introduction}

To understand the temporal and spatial evolution of highly extended lithosphere, it is

47 important to analyze regions with a complete record of subsidence and crustal thinning using

48 theoretical models that do not make prior assumptions about the style, duration or magnitude of

49 stretching. Many questions remain about the importance and form of depth-dependent stretching

50 during rifting. Some models call for a lateral offset between the locus of extension in the crust

51 and mantle lithosphere (Wernicke, 1985; Hopper and Buck, 1998) or an increase or decrease in

52 the amount of stretching with depth (Davis and Kusznir, 2004). The most extreme examples of

53 depth-dependent stretching are associated with lower crustal flow during the extension of hot

54 lithosphere with a thick crust (McKenzie et al., 2000) or with denudation of the lower crust

55 and/or lithospheric mantle during the extension of cold lithosphere (Whitmarsh et al., 2001;

56 Lavier and Manatschal, 2006). Variations in stretching with depth can have a significant effect

57 on the thermal and subsidence history of basins and margins (Buck et al., 1988) and thus are

58 important for practical applications, such as modeling the maturation of hydrocarbons.

59 Despite the importance of understanding variations in stretching with depth through the

60 lithosphere, characterizing these variations is often difficult because of a lack of observations.

61 Sedimentary infill is a record of subsidence, which is sensitive to thinning throughout the

62 lithosphere. However, many well-studied margins are sediment-starved, and the subsidence

63 record is difficult to reconstruct in the absence of independent constraints on paleobathymetry.

64 In order to gain a complete picture of extension throughout the lithosphere, we must examine a

65 basin whose crustal structure can be accurately constrained (i.e., from wide-angle refraction data)

66 and that contains a complete sedimentary record (Davis and Kusznir, 2004). The eastern Black

67 Sea (EBS) is an extensional basin that is thought to have opened in the Upper Cretaceous/early 
68 Cenozoic (Zonenshain and Le Pichon, 1986; Robinson et al., 1995b) and contains 8-10 km of

69 sediments that record the Cenozoic history of this basin. Results of previous seismic refraction

70 and gravity studies imply that significant degrees of extension were involved in the formation of

71 this basin $(\beta>4)$ (Letouzey et al., 1977; Belousov et al., 1988; Starostenko et al., 2004). These

72 characteristics, together with the availability of a new wide-angle seismic dataset (Minshull et

73 al., 2005), industry seismic reflection data, and well control (Robinson et al., 1995b), make the

74 EBS an ideal natural laboratory for studying extensional processes. Furthermore, the Black Sea

75 is a frontier basin for hydrocarbon exploration, making it a timely target for study (Robinson et

76 al., 1996).

77 For the last thirty years, extensional sedimentary basins and passive margins have been

78 modeled using a range of kinematic and dynamic models. Kinematic models are concerned with

79 the movement of material and heat without reference to force, rheology or mass. The simplest

80 kinematic models assume that rifting is instantaneous and that the lithosphere thins uniformly

81 (McKenzie, 1978). More realistic kinematic models allow for finite-duration rifting and non-

82 uniform thinning of the lithosphere in one or two dimensions. Dynamic models attempt to solve

83 the general problem of how body forces act upon lithospheric rheology to deform the lithosphere

84 and generate subsidence. Many sophisticated dynamic models exist, but they are predicated upon

85 our understanding of the rheology of the crust and lithosphere, which is still relatively poor. The

86 vast majority of kinematic and dynamic models solve the forward problem whereby crustal

87 deformation and subsidence are calculated from a prescribed lithospheric stretching history

88 rather than the inverse problem, whereby the spatial and temporal history of lithospheric

89 deformation is extracted from subsidence and crustal data. The inverse approach is advantageous

90 because it allows trade-off between the governing parameters to be investigated in a formal way, 
91 and we adopt this approach here. Kinematic models are preferable for use within an inverse

92 scheme because they are simpler and less computationally intensive than dynamic models.

93 To extract an extensional history of the EBS and to address generic questions about

94 continental extension, we use a kinematic algorithm that does not make any assumptions

95 regarding the timing, duration, location, or magnitude of extension (White and Bellingham,

96 2002). This method inverts the backstripped sedimentary record for spatial and temporal

97 variations in strain rate assuming pure-shear extension. We also present the results of applying

98 an extended version of this algorithm that allows for depth-dependent stretching without

99 assuming its existence or style (Edwards, 2006; Edwards et al., in prep). Although the EBS has

100 been the subject of subsidence analysis and other modeling in previous studies (Robinson et al.,

101 1995a; Spandini et al., 1996; Meredith and Egan, 2002; Cloetingh et al., 2003; Nikishin et al.,

102 2003), the work presented here makes the fewest assumptions about the extensional history. We

103 also explore the consequences of changing the most controversial variables required for

104 subsidence analysis of deep basins and margins: paleowater depth and elastic thicknesses, $T_{e}$.

105 2. Geology of the Black Sea

106

The Black Sea region has experienced several episodes of extension and shortening since

107 the Permian (Yilmaz et al., 1997; Robertson et al., 2004), and it continues to experience

108 deformation today in response to the northward movement of the Arabian plate and westward

109 escape of the Anatolian block along the North and East Anatolian Faults (McKenzie, 1972;

110 McClusky et al., 2000). The basin is generally considered to have formed in a back-arc

111 extensional environment because of its close spatial association with the subduction of both the

112 Paleo- and Neo-Tethys Oceans, but the timing and style of this opening history remain

113 controversial (Zonenshain and Le Pichon, 1986; Okay et al., 1994; Banks et al., 1997). The 
114 Black Sea can be subdivided into eastern and western basins based on its basement structures;

115 these sub-basins are separated by the Archangelsky and Andrusov Ridges, which constitute a 116 system of buried basement ridges that run SW-NE through the center of the Black Sea and are

117 collectively called the Mid Black Sea High (Fig. 1). Based on plate reconstructions and the ages

118 of volcanic rocks with arc signatures located in the western Pontides, in northern Turkey (Görür,

119 1988; Okay et al., 1994), a Middle to Upper Cretaceous opening is estimated for the western

120 Black Sea (WBS). Analysis of seismic refraction and gravity datasets give a crustal thickness of

$1217-8 \mathrm{~km}$ and velocities consistent with a "basaltic" composition in the basin center, suggesting

122 that rifting in the WBS culminated in seafloor spreading (Letouzey et al., 1977; Belousov et al.,

123 1988; Starostenko et al., 2004).

124 Much less agreement exists on the timing of opening in the EBS. Alternative theories call

125 for a primary phase of opening in the Jurassic, Cretaceous (Zonenshain and Le Pichon, 1986;

126 Okay et al., 1994; Nikishin et al., 2003), Early Eocene/Paleocene (Robinson et al., 1995b; Banks

127 et al., 1997), or Eocene (Kazmin et al., 2000; Vincent et al., 2005). The age of the EBS infill is

128 estimated to be Cenozoic (Finetti et al., 1988); this observation together with documented

129 structural relationships at the edges of the basin, ages of arc magmatic products, and plate

130 reconstructions indicate that major basin-forming events probably occurred in the late Mesozoic

131 or early Cenozoic (Zonenshain and Le Pichon, 1986; Okay et al., 1994; Banks et al., 1997;

132 Boztug et al., 2004). Apatite fission track data suggest that arc magmatism in the Central

133 Eastern Pontides lasted until the mid-Paleocene and was followed by uplift related to the onset of

134 continental collision in the Late Paleocene to Early Eocene (Boztug et al., 2004), implying that

135 back-arc extension in the EBS occurred between the Upper Cretaceous and early Cenozoic.

136 Stratal relationships on the Shatsky Ridge where it is exposed onshore in Georgia also indicate 
137 an Upper Cretaceous/Paleocene-Eocene timing for opening. In this location, sediments as young 138 as Danian (earliest Paleocene) are unconformably overlain by mudstones of Upper Eocene age

139 (Banks et al., 1997). Likewise, Eocene mudstones overlie Cretaceous chalks and volcanic rocks

140 on Shatsky Ridge (Rudat and Macgregor, 1993). Carbonate rocks of Upper Cretaceous age were

141 drilled at Chaladidi-13, Chaladidi-14, Ochamchira and Akcakoca (Fig. 1), whereas the early

142 Cenozoic section is typically comprised of mudrocks, implying that basin deepening occurred in 143 this time interval.

144 Most reconstructions show the EBS opening in a NE-SW direction by the rotation of the 145 Shatsky Ridge away from the Mid Black Sea High (Okay et al., 1994; Nikishin et al., 2003)

146 (Figs. 1 and 2). It is uncertain whether opening of the EBS concluded with initial seafloor

147 spreading; previous gravity and seismic studies have estimated a crustal thickness of $\sim 10-11 \mathrm{~km}$

148 in the basin center and seismic velocities lower than average oceanic crust, implying a thinned

149 continental origin (Belousov et al., 1988; Starostenko et al., 2004), although this interpretation is 150 disputed (Letouzey et al., 1977; Zonenshain and Le Pichon, 1986). Preliminary results from the 151 new wide-angle dataset indicate a crustal thickness as small as $7 \mathrm{~km}$ and velocities consistent 152 with thinned continental crust or oceanic crust produced in a back-arc setting (Minshull et al., 153 2005). Further work is needed to ascertain the nature of this crust. For the purposes of this paper, 154 we will assume that crust in the center of the EBS is stretched continental crust. We discuss the 155 implications of our results if crust in the center of the EBS is oceanic in Section 8.3.

\section{3. Database: Seismic Reflection and Well-log Data}

157 Several seismic and lithological datasets are available in the EBS that can be used to 158 derive inputs for subsidence analysis. Academic and industry seismic reflection profiles have 159 previously been acquired throughout the EBS. We have chosen to model the subsidence history 
160 along a transect where coincident wide-angle data have recently been collected (Fig. 1). It lies

161 orthogonal to the thinnest crust in the basin as delineated by gravity data and is roughly parallel

162 to the inferred opening direction (Starostenko et al., 2004). This line also encompasses major

163 extensional features in the EBS. It begins near Samsun, crosses Sinop Trough, Archangelsky

164 Ridge, the basin center, Shatsky Ridge, Tuapse Trough and terminates at the Russian margin

165 west of Tuapse (Figs. 1 and 2).

166 Many significant characteristics of the EBS basin can be observed in the seismic

167 reflection profiles (KDZ 91-43 and Line 8040) along this line (Fig. 2). Sediments in the center

168 of the basin are remarkably undeformed, suggesting that shortening due to the northward

169 movement of the Arabian plate is limited to the eastern edge of the Black Sea (Rangin et al.,

170 2002) and to the Greater Caucaus (McClusky et al., 2000; Saintot and Angelier, 2002). Within

171 the sedimentary section, several units can be identified, including the Maikop Formation, a clay-

172 rich unit that constitutes the major potential hydrocarbon source rock in the Black Sea (Robinson

173 et al., 1996). The Top-of-Cretaceous horizon can also be identified, which is interpreted to

174 represent the contact between Eocene and Paleocene mudstones and Upper Cretaceous carbonate

175 and volcanogenic sedimentary rocks (Zonenshain and Le Pichon, 1986; Robinson et al., 1996).

176 To the north of the basin center lies the Shatsky Ridge, a basement high bound to the south by

177 one or more large normal faults (Banks et al., 1997), but whose northern side is being flexed

178 beneath the Greater Caucaus, generating a small foreland basin, the Tuapse Trough (Fig. 2). The

179 Archangelsky Ridge has very steep sides, but few extensional structures can be discerned within

180 the crust. Farther south lies the Sinop Trough, which is also interpreted to be extensional in

181 origin; this sub-basin deepens to the west and ultimately connects to the WBS. 
Information on the age and lithology of the stratigraphic units in the Black Sea region

183 comes from drilling and onshore geologic mapping (Fig. 1, Appendix). Sediments as old as Late

184 Miocene have been sampled in the center of the Black Sea by three DSDP sites (Fig. 1) (Ross et

185 al., 1978), and sediments as old as Late Jurassic have been recovered by industry wells at the

186 margins of the Black Sea (e.g., Ochamchira and Akcakoca; Fig. 1) (Zonenshain and Le Pichon,

187 1986; Banks et al., 1997). The lithology and age of these units are used in subsidence analysis

188 and provide critical information on the opening history of the EBS (see the Appendix for brief

189 review).

190 4. Deriving inputs for subsidence analysis

191 For subsidence analysis, we require a series of layers with assigned ages, lithologies and

192 paleowater depth histories and a template for the initial configuration of the crust and mantle

193 lithosphere. Each of these inputs is described below.

$194 \quad$ 4.1 Stratigraphic framework

195 In order to estimate the ages and lithologies of sedimentary units in the eastern Black Sea,

196 seismic stratigraphic horizons have been tied to well control at the edges of the basin using 2D

197 and 3D industry seismic datasets (Figs. 2 and 3) (Robinson et al., 1996). The geologic time scale

198 of Gradstein et al. (2004) is used. Links between chronostratigraphy and regional stratigraphy are

199 taken from Jones and Simmons (1997). There are several difficulties in developing a

200 stratigraphic framework for the EBS. First, all of the wells that penetrate the entire Cenozoic

201 section and part of the Mesozoic section are necessarily located on the margins of the Black Sea

202 or onshore, while strata of this age lie at depths $>8 \mathrm{~km}$ in the center of the basin (Fig. 1). Thus,

203 stratigraphic sections at well locations are comparatively condensed, and some uncertainties are

204 associated with tracing major horizons from well locations into the basin center. Furthermore, 
most offshore well control lies in the WBS (e.g., Akcakoca, Fig. 1). Tracing horizons from the

206 western basin to the eastern basin is complicated by the presence of the Mid Black Sea High,

207 which prevents direct correlation of horizons older than Late Eocene (Banks et al., 1997).

208 However, correlations presented here use all available well control and seismic reflection data in

209 the region and are consistent with other recent interpretations (Robinson et al., 1995a; Spandini

210 et al., 1996; Meredith and Egan, 2002), and thus are the best available estimates of the ages and

211 lithologies of the infill of the EBS.

212 A second important issue in using seismic reflection data to constrain stratigraphy is

213 conversion between two-way travel time and depth (Fig. 2). We used interval velocities derived

214 from stacking velocities provided by BP for depth conversion (Fig. 2). Because most of the

215 seismic reflection data located in the Black Sea were acquired with either a 4- or 6-km-long

216 streamer, these data cannot constrain the velocities of deeper strata $(\sim>4-6 \mathrm{~km})$. The inset in

217 Figure 2a shows the average depth-time relationship for sediments with upper and lower bounds

218 based on +/- one standard deviation in velocity, calculated by comparing velocity functions over

219 a 150-km-long segment within the center of the EBS. Part of the variation in velocity structure

220 included in this envelope could be caused by real changes in sediment properties and basin

221 structure. However, it provides an illustration of approximate uncertainties. The standard

222 deviation in velocity increases steadily with depth from $\sim 60 \mathrm{~m} / \mathrm{s}$ at $3 \mathrm{~s}$ to $\sim 140 \mathrm{~m} / \mathrm{s}$ at $5.5 \mathrm{~s}$.

223 Below this depth, the standard deviation increases more rapidly to $345 \mathrm{~m} / \mathrm{s}$ at $8.75 \mathrm{~s}$, at the Top-

224 of-Cretaceous horizon (Fig. 2b); this increase is associated with depths at which velocities would

225 be less well constrained due to short streamer length. These uncertainties in velocity are

226 associated with uncertainties in depth of $\sim 20 \mathrm{~m}$ at $3 \mathrm{~s}, \sim 275 \mathrm{~m}$ at $5.5 \mathrm{~s}$, and $\sim 1000 \mathrm{~m}$ at $8.75 \mathrm{~s}$. A

227 comparison between stacking velocities used by BP and velocities derived by preliminary 
modeling of wide-angle seismic data (Minshull et al., 2005), which have a sufficiently large

229 aperture to constrain the velocities of deep sediments, shows that the two velocity functions are

230 very similar.

\section{$231 \quad 4.2$ Paleowater depth}

The paleowater depth (PWD) of each horizon is required for backstripping, but PWD

233 histories are notoriously difficult to constrain for deep-water basins and continental margins.

234 Consequently, as for any subsidence study of a deep-water basin or margin, PWD constitutes a

235 significant source of uncertainty in our analysis of this region. Variations in water depth of at

236 least $2200 \mathrm{~m}$ are possible based on the current bathymetry of the Black Sea, and some authors

237 estimate even more dramatic variations (Robinson et al., 1995a; Spandini et al., 1997). Previous

238 subsidence models have assumed or inferred a large range of PWD histories: (1) Robinson et al.

239 (1995a) and Cloetingh et al. (2003) use the results of the forward model of Spandini et al. (1996)

240 to infer PWD variations as great as $4500 \mathrm{~m}$ through the Cenozoic; (2) Nikishin et al. (2003)

241 propose shallow PWD in the mid-Cretaceous and deep PWD thereafter; (3) Meredith and Egan

242 (2002) assume that all of the accommodation space was filled with sediment throughout the

243 history of the basin in the 2D portion of their analysis (Fig. 3). In reality, very few constraints

244 exist on the PWD of different intervals in the Black Sea except those than can be inferred from

245 interpreted lithologies within the basin and stratigraphic relationships (e.g., Shatsky Ridge).

246 Here, we consider three end-member PWD cases (Fig. 3): (1) The EBS was shallow at

247 the end of the Cretaceous/beginning of the Cenozoic (0-200 m), after which it was deep (2000-

$2482200 \mathrm{~m}$ ) until the present; (2) The EBS was deep (2000-2200 m) at the end of the Cretaceous and

249 remained so until the present; (3) The EBS was shallow (0-200 m) until the end of the Pliocene

250 and deep (2000-2200 m) afterwards. For each of these cases, the depth of the seabed at $0 \mathrm{Ma}$ is 
251 set to the current bathymetry in the EBS, where the maximum depth is $\sim 2200 \mathrm{~m}$. These histories

252 are relatively simple yet encompass the key characteristics of paleowater depth histories

253 employed in previous studies (Fig. 3).

\section{$254 \quad 4.3$ Crustal and lithospheric template}

In addition to information on the depth, age, lithology, and paleowater depth of

256 sedimentary horizons, the crustal and lithospheric template must be defined (White and

257 Bellingham, 2002). Crustal thickness increases south of the Black Sea from $35 \mathrm{~km}$ near the edge

258 (Çakir and Erduran, 2004) to $46 \mathrm{~km}$ in the eastern Anatolian plateau (Zor et al., 2003). These

259 crustal thicknesses are likely affected by recent shortening due to the northward movement of the

260 Arabian plate. We therefore have set the initial crustal thickness to $32 \mathrm{~km}$, consistent with

261 preliminary results from modeling of wide-angle seismic data near the SW edge of the basin

262 (Minshull et al., 2005).

263 Initial lithospheric thickness and temperature structure are more difficult to determine.

264 Constraints on the present-day temperature of the lithosphere beneath the Black Sea region come

265 primarily from measurements of seismic velocity and attenuation. The results of $p$-wave

266 tomography and $s$-wave attenuation studies indicate that the mantle beneath the eastern Black

267 Sea has higher velocities and is associated with less attenuation than the surrounding regions

268 (e.g., Anatolia), suggesting comparatively cold mantle temperatures (Hearn and Ni, 1994; Gök et

269 al., 2003; Al-Lazki et al., 2004). Heat flow values within the basin are complicated by the thick

270 sedimentary infill, and thus are difficult to interpret (Kutas et al., 1998). Although these lines of

271 evidence provide constraints on mantle temperatures at present, they may not accurately reflect

272 thermal conditions at the time of rifting. Seismic reflection profiles do not show evidence for

273 seaward dipping reflections or other indications of abundant synrift magmatism nor is there any 
274 evidence for flood basalt volcanism onshore, so we infer that mantle temperatures were not

275 unusually high at this time. Consequently, we assume a 'normal' temperature for the base of the

276 lithosphere of $1333^{\circ} \mathrm{C}$, which is consistent with a potential temperature of $1300^{\circ} \mathrm{C}$ for the upper

277 mantle (Bellingham and White, 2002).

278 Even less information is available regarding lithospheric thickness. White and

279 Bellingham (White and Bellingham, 2002) demonstrated that the ratio of crustal to lithospheric

280 thickness is more important in controlling the outcome of subsidence analysis than the absolute

281 value assigned to either parameter. Assuming that the top of the crust is at sea level, they

282 balanced a section of continental lithosphere with a standard mid-ocean ridge to demonstrate that

283 a ratio of crustal to lithospheric thickness of $\sim 1: 3.6$ is in isostatic equilibrium (White and

284 Bellingham, 2002). In the case of the EBS, this assumption is justified because lithological data

285 suggest that Upper Cretaceous sediments were deposited in a shallow water environment

286 (Appendix). For our initial crustal thickness of $32 \mathrm{~km}$ and an average crustal density of 2.78

$287 \mathrm{~g} / \mathrm{cm}^{3}$, this ratio prescribes a lithospheric thickness of $\sim 120 \mathrm{~km}$, which we use for this study.

$288 \quad$ 4.4 Elastic Thickness, $\boldsymbol{T}_{e}$

289 The flexural rigidity of the lithosphere, often expressed as elastic thickness $\left(T_{e}\right)$, dictates

290 how the lithosphere responds to a load. If the lithosphere is strong, a load is compensated over a

291 large area, and if the lithosphere is weak, a load is compensated locally. Although $T_{e}$ may be a

292 fundamental characteristic modulating the response of the lithosphere to a range of loading

293 phenomena, its estimation is controversial, even in the oceanic domain (Burov and Diament,

294 1995; McKenzie and Fairhead, 1997; Perez-Gussinye et al., 2004; Bry and White, 2007). Here,

295 we backstrip and model subsidence using a range of values for $T_{e}(0$ to $100 \mathrm{~km})$ and discuss the

296 consequences of varying $T_{e}$ for the results and data fit in Section 8.2. 


\section{Data Preparation}

The parameters shown in Figure 3 and described in Section 4 are used to flexurally

299 backstrip each sedimentary layer using the method of Steckler and Watts (1978) and Sclater and

300 Christie (1980), modified after Jones et al. (2004). The backstripping method applied here allows

301 for variable PWD across the basin, which is important for correctly modeling the edges of the

302 basin. We scale present-day bathymetry along each transect to create a series of profiles of PWD

303 across the basin for each horizon. Following backstripping, a filter is applied to each horizon to

304 remove small-scale structures that might be associated with individual faults so that regional

305 tectonic subsidence can be isolated for strain rate inversion (Bellingham and White, 2002; Jones

306 et al., 2004). We filtered our horizons using a cosine filter with a length of $40 \mathrm{~km}$, although

307 using different filter lengths (e.g., $20 \mathrm{~km}$ ), or not using a filter at all, does not alter the results of

308 inversion (Jones et al., 2004).

309 Previous studies indicate that the differences in water-loaded stratigraphy arising from

310 changing the lithology used for backstripping are sufficiently minor that they do not significantly

311 change the results of strain rate inversion (Bellingham and White, 2002). Paleowater depth and

312 elastic thickness, however, have much larger impacts on the amount of tectonic subsidence

313 implied after backstripping (see online supplementary material). Below, we apply both depth-

314 uniform and depth-dependent strain rate inversions to all three PWD cases for a range of values

315 of $T_{e}(0-100 \mathrm{~km})$.

\section{6. Strain Rate Inversion}

317 We used the backstripped stratigraphy and parameters described above as input into

318 strain rate inversion (White and Bellingham, 2002; Jones et al., 2004). For a complete

319 description of other variables assigned for modeling, see White and Bellingham (2002). This 
method uses water-loaded stratigraphic horizons to invert for spatial and temporal variations in

321 strain rate using a kinematic approach. Strain rate is considered to be the fundamental parameter

322 describing extension, and it can be used to calculate stretching factors, $\beta$ (White, 1993). We first

323 apply an algorithm that assumes depth-uniform stretching (White and Bellingham, 2002; Jones et

324 al., 2004). We then apply a new version of this algorithm that allows stretching to vary with

325 depth, but does not presuppose either the existence or style of depth dependence (Edwards, 2006;

326 Edwards et al., in prep).

327 The forward model of both algorithms, which relates strain rate to subsidence, involves

328 four steps (White, 1993; White and Bellingham, 2002). First, a given distribution of strain rate

329 in space and time dictates a velocity field for the deformation of the lithosphere. Secondly,

330 lithospheric thinning perturbs the thermal structure by bringing warmer asthenosphere to

331 shallower levels. The thermal evolution of the lithosphere is solved using the $2 \mathrm{D}$ heat flow

332 equation, including horizontal and vertical advective terms. Thirdly, if a linear relationship is

333 assumed between temperature and density, the calculated temperature structure of the lithosphere

334 can be used to determine temporal and spatial variations in density. Lateral and vertical density

335 variations impose loads on the lithosphere. Lastly, these loads result in subsidence or uplift; the

336 magnitude and shape of this subsidence is moderated by $T_{e}$.

337 The relationship between subsidence and strain rate outlined above for the forward model

338 can be used to solve the inverse problem, in which the strain rate field is determined from known

339 stratigraphy. A strain-rate history is found by minimizing the difference between observed and

340 predicted stratigraphy. To regularize the inversion, first and second derivative smoothing in time

341 and space and positivity weighting functions are also included in the misfit function (White and

342 Bellingham, 2002). In the depth-uniform algorithm, strain rate is also fixed to be constant with 
343 depth, and the global minimum of the misfit function is found using a conjugate gradient method

344 that performs successive line minimizations (Powell's algorithm) (Press et al., 1992).

345 Additional considerations are needed in allowing for variations in extension with depth

346 during inversion. First, mass must be conserved (i.e., the cumulative strain across the model must

347 be identical at all depths). Mass conservation is easily achieved if strain rate does not vary with

348 depth; to ensure that this requirement is still met in the depth-dependent algorithm, we use depth-

349 dependent strain-rate distributions based on periodic functions (e.g., Fourier series) horizontally

350 and linear splines with depth (Edwards, 2006; Edwards et al., in prep). During inversion, we

351 invert for the coefficients of these periodic functions, which allows us to retrieve the depth

352 dependency of strain rate whilst automatically conserving mass and honoring the boundary

353 conditions. Secondly, the inversion routine is weighted to favor depth-independent strain rate

354 solutions, so that depth-dependent stretching is only invoked when pure-shear stretching cannot

355 explain the observations. Finally, when depth-dependent stretching is required to fit the data, the

356 form of depth dependency is not prescribed. The details of the depth-dependent algorithm are

357 described by Edwards (2006).

358 7. Results

359 The results of inverting this line assuming Airy isostasy (i.e., $T_{e}=0 \mathrm{~km}$ ) using both

360 depth-uniform and depth-dependent algorithms for the three PWD cases described in Section 4.2

361 are presented in Figures 4-6 and discussed in Sections 7.1-7.3; key strain rates and errors are

362 given in Table 1. The effects of backstripping and inverting for stratigraphy with other values of

$363 T_{e}$ are illustrated in Figure 7 and discussed in Section 7.4. 


\subsection{Case 1: Shallow at the end of the Cretaceous and deep afterwards}

Two primary strain rate events can be identified following inversion. The first event continues from the end of the Cretaceous (the age of the oldest horizon included in inversion)

367 until the Middle Eocene ( 65-45 Ma; Fig. 4, Table 1). A period of quiescence follows until the

368 Middle Miocene ( 15-10 Ma), when a second, smaller subsidence anomaly is evident. This event

369 is observed across the profile but is most pronounced in the northeastern parts of the profiles.

370 The match between observed and predicted tectonic stratigraphy is excellent (Fig. 4, Table 1).

371 This strain rate history predicts a maximum cumulative $\beta$ (from 65 Ma to present) of $\sim 4.8$, which

372 is similar to the $\beta$ calculated based on initial velocity modeling of coincident wide-angle data

373 (Minshull et al., 2005) (Fig. 4).

374 The depth-dependent inversion yields a very similar temporal strain rate distribution to 375 the depth-uniform inversion. The fits between observed and predicted horizons are also good

376 (Table 1). A significant result of the depth-dependent inversion is the relatively simple

377 distribution of strain rates in depth. The depth slice at 58.5 Ma in Figure 4 shows that the strain

378 rate event broadens with depth beneath the center of the basin, but is otherwise symmetric. The 379 most convincing depth dependence observed in this model is associated with Sinop Trough, on 380 the southern side of the basin. Here, an increase in strain rate with depth is apparent, and this 381 event appears to coalesce with the strain rate event associated with the basin center.

\section{$382 \quad$ 7.2 Case 2: Deep from the end of the Cretaceous to the present}

Although some strain rate events are required in the Cenozoic even if the basin has been

384 deep since the end of the Cretaceous (Fig. 5, Table 1), these are not as great in magnitude as the 385 primary strain rate event found for Case 1. A small strain rate event can be observed at $65 \mathrm{Ma}$, 386 which widens and reaches its peak value in the Late Eocene. A second anomaly around 15-10 
Ma that is focused in the northern part of the basin is also evident in the results from Case 2,

388 similar to the one observed in Case 1; the 15-10 Ma events for both Cases 1 and 2 are also of

389 similar magnitude. The results of inversion for this PWD case also yield a very good fit between

390 observed and predicted backstripped stratigraphy (Table 1).

391 A much smaller cumulative $\beta(\sim 2)$ is indicated by the strain rate distribution for Case 2

392 (Fig. 5). This result suggests that even if the EBS already contained 2000-2200 $\mathrm{m}$ of water by the

393 end of the Cretaceous, additional tectonic subsidence is required to explain the present-day basin.

394 The discrepancy between the $\beta$ value of Case 2 and the one calculated from the results of initial

395 modeling of wide-angle seismic data (Fig. 5) might be explained by significant extension before

396 the Cenozoic that would not be recovered by the sediment record employed in this study, which

397 begins at $65 \mathrm{Ma}$.

398 A similar strain rate distribution is recovered by depth-dependent inversion. As in Case 1,

399 almost no depth dependency is associated with the strain rate distribution at the end of

400 Cretaceous times except a slight broadening towards the base of the lithosphere.

$401 \quad 7.3$ Case 3: Shallow until the end of the Pliocene and deep afterwards

402 Inversion of horizons backstripped using the third PWD case yields the worst fits

403 between observed and predicted horizons (Fig. 6, Table 1). One primary strain rate event is

404 recovered from 20-0 Ma, and the cumulative $\beta$ is $\sim 14$ (Fig. 6). Other short-wavelength strain rate

405 peaks are also recovered at earlier times. The depth-dependent inversion is more successful in

406 matching observed and predicted backstripped horizons, but still has the highest associated misfit

407 of all of the PWD cases. Again, the significant strain rate event occurs between 20-0 Ma, and

408 short-wavelength fluctuations in strain rate can be observed in time and space.

$409 \quad$ 7.4 Effect of $\boldsymbol{T}_{e}$ on results 
411 the consequences of non-zero $T_{e}$, we have also backstripped and inverted stratigraphy for PWD

412 Cases 1 and 2 with larger values for $T_{e}(20,50$, and $100 \mathrm{~km})$; PWD Case 3 was excluded due to

413 the poor data fits following inversion even for Airy isostasy. When larger values of $T_{e}$ are used to

414 backstrip and model stratigraphy, the primary effect is that higher strain rates and larger

415 stretching factors are recovered by inversion (Fig. 7). One of the primary reasons for this result

416 is that the tectonic subsidence recovered by backstripping a stratigraphic section using a large $T_{e}$

417 is greater than that recovered by backstripping the same section using small $T_{e}$ because the

418 lithosphere is less sensitive to loading (or unloading) when $T_{e}$ is higher (see online

419 supplementary material). For example, a maximum of $\sim 5 \mathrm{~km}$ of tectonic subsidence is suggested

420 for PWD Case 1 when $T_{e}$ is $0 \mathrm{~km}$, and $\sim 6.1 \mathrm{~km}$ when $T_{e}$ is $50 \mathrm{~km}$. As a result, the strain rates and

421 stretching factors recovered by inverting tectonic subsidence for high values of $T_{e}$ are

422 correspondingly large. A maximum stretching factor of $\sim 4.8$ is recovered by inversion for PWD

423 Case 1 when $T_{e}$ is $0 \mathrm{~km}$, and $\sim 7.4$ when $T_{e}$ is $50 \mathrm{~km}$.

424 Although the inferred magnitude of extension increases for increasing values of $T_{e}$, the 425 temporal and spatial patterns recovered using different values of $T_{e}$ are similar (Fig. 7). The 426 strain rate distributions for larger values of $T_{e}$ are slightly more focused in the center of the basin 427 than those for the Airy isostasy case, reflecting the sharper basin geometries after backstripping 428 using large $T_{e}$ (Fig. 7). The fit between observed and predicted horizons worsens with increasing $429 T_{e}$, particularly for values between 0 and $20 \mathrm{~km}$. 


\section{Discussion}

\section{8.1. Choosing between PWD cases}

Strain rate inversion of the three PWD cases described above shows that Cases 1 and 2

433 produce acceptable data fits (Table 1) and plausible strain rate distributions. The inability of

434 either inversion algorithm to match observed and predicted tectonic subsidence for Case 3

435 indicates that the PWD assumptions in this case are unrealistic. Lack of independent evidence

436 for Miocene or Pliocene extension casts further doubt over the validity of Case 3. Although

437 inversions for both Cases 1 and 2 fit the data equally well, we prefer Case 1 for the following

438 reasons. First, the assumptions in Case 1 about PWD variations through time are more consistent

439 with what is known about lithology and geology of each of the intervals from the edges of the

440 basin. Secondly, Case 1 is supported by limited examples of growth in seismic reflection sections

441 from the EBS (Fig. 8).

442 Where Upper Cretaceous sections have been described from drilling or onshore mapping,

443 they are primarily composed of carbonate and/or volcanogenic sedimentary rocks, whereas the

444 Paleocene/Eocene interval comprises pelagic mudrocks (Robinson et al., 1996). Furthermore,

445 Eocene mudstones have been observed to unconformably overly Paleocene and Cretaceous units

446 on Shatsky Ridge where it has been drilled and studied in outcrop onshore (Banks et al., 1997)

447 and Cretaceous chalks, tuffs and volcanic rocks where they were dredged on Archangelsky

448 Ridge (Rudat and Macgregor, 1993). These stratal relationships and changes in lithology are

449 most easily interpreted as representing an increase in PWD. This analysis shows that an

450 extensional strain rate event that predicts values for $\beta$ similar to those calculated from initial

451 results of modeling wide-angle seismic data can explain a reasonable change in PWD at this

452 level. 
An obvious difficulty in dating the timing of extension within the EBS is the near-

454 absence of easily interpretable evidence of extension within any stratigraphic unit, such as

455 growth related to fault movement. However, limited evidence is available that corroborates the

456 results of Case 1 discussed above. For example, possible synrift fanning of early Cenozoic

457 sediments can be observed in Sinop trough (Fig. 8a) (Rangin et al., 2002). Additionally, possible

458 evidence of growth is occasionally observed in the basin, both adjacent to the Turkish margin

459 and in the center (Fig. 8b). If basin opening occurred quickly, as suggested by onshore evidence

460 (Ustaömer and Robertson, 1997), classic sedimentary features such as growth might not be easily

461 identified.

462 Although we favor Case 1, our analysis does not allow us to eliminate Case 2. The

463 results of Case 2 show that even if the EBS was already 2000-2200 m deep at the end of the

464 Cretaceous, additional tectonic subsidence is still required in the early Cenozoic to explain the

465 stratigraphic architecture.

$466 \quad$ 8.2 What is the elastic thickness?

467 As discussed in Section 7.4, the primary effect of using larger values of $T_{e}$ to backstrip

468 and model the profiles is that greater amounts of tectonic subsidence are implied, and

469 correspondingly larger strain rates and stretching factors are recovered by inversion. The results

470 can be judged in terms of both misfit between data and predictions following inversion and

471 implied stretching factors. Smaller data misfits are associated with smaller values of $T_{e}(<20 \mathrm{~km})$

472 (Fig. 7). The misfit function flattens for $T_{e}$ values greater than $20 \mathrm{~km}$ because the associated

473 flexural wavelengths are similar to or larger than the spatial dimensions of the eastern Black Sea

474 itself. For PWD Case 1, the results for $T_{e}$ values of $50 \mathrm{~km}$ or higher also have very high

475 maximum stretching factors ( $>7)$ since stretching factors of 5.5-6 are commonly likened to 
seafloor spreading. They also predict a crustal thickness of only $\sim 4 \mathrm{~km}$ at the center of the basin,

477 which is smaller than the value indicated by wide-angle seismic data. For PWD Case 2, the

478 stretching factors recovered for all values of $T_{e}$ are reasonable. These observations lead us to

479 favor the interpretation that the eastern Black Sea was relatively weak $\left(T_{e} \leq 20 \mathrm{~km}\right)$ during much

480 of the Cenozoic. This result is consistent with an estimate of $2.3 \mathrm{~km}$ for $T_{e}$ obtained by matching

481 the curvature of the Shatsky Ridge where it is flexed beneath the Caucaus with predicted curves

482 for a point-loaded, broken elastic beam (Fig. 7d) (Turcotte and Schubert, 2002).

\section{$483 \quad 8.3$ Implications of crustal type in the basin center for modeling results}

The analysis presented above assumes that the EBS is floored by thinned continental

crust. However, the nature of crust in the basin center is unknown, although initial results from a

486 recently acquired wide-angle seismic dataset in the EBS yield crustal velocities and thicknesses

487 along this line that could be compatible with either thinned continental crust or oceanic crust

488 produced in a back-arc setting (Minshull et al., 2005). Therefore, we must consider the

489 consequences for our results if the EBS is floored by oceanic crust. The results from Case 2 most

490 closely approximate the consequences of having oceanic crust in the center of the EBS. The

491 total amount of water-loaded subsidence observed in this model $(\sim 3250 \mathrm{~m})$ is similar to the

492 amount that would be anticipated for 65-m.y.-old oceanic crust (Parsons and Sclater, 1977).

493 However, the EBS subsidence curve is not exponential like the depth-age relationship of Parsons

$494 \&$ Sclater (1977), implying that not all of this subsidence can be accounted for by cooling and

495 sinking of oceanic lithosphere even if the EBS is floored by oceanic crust.

4968.4 Evidence for regional shortening in last 20 m.y.

497 A second subsidence anomaly is evident in the results of both the depth-dependent and 498 depth-uniform strain rate inversion for Cases 1 and 2, which reaches its peak around 15-10 Ma, 
499 but continues until $0 \mathrm{Ma}$ (Figs. 4 and 5). This inversion algorithm interprets all such subsidence

500 events as resulting from extensional strain. Although small subsidence anomalies are observed

501 across the entire profile, it is primarily concentrated in the northeastern part of the basin. We

502 propose that this event corresponds to subsidence resulting from shortening concentrated at the

503 northern margin resulting from northward movement of the Arabian plate. This event is

504 manifested in the flexure of the Shatsky Ridge beneath the Greater Caucaus (Fig. 2), but is also

505 supported by the ages of syn-orogenic magmatism, reconstructions and paleostress indicators

506 (Yilmaz et al., 1997; Saintot and Angelier, 2002; Nikishin et al., 2003). This observation is also

507 consistent with GPS measurements of present-day deformation in the region, which show that

508 some shortening is accommodated in the Caucaus, but that there is little evidence for internal

509 deformation within the Black Sea itself (Reilinger et al., 2006). Cloetingh et al. (2003) and

510 Nikishin et al. (2003) have also attributed basin-wide tectonic deepening of the EBS in the late

511 Cenozoic to shortening.

\section{$512 \quad$ 8.5 Depth-uniform and depth-dependent stretching}

513 One of the most important results of this study is the ability of a largely depth-uniform

514 stretching model to account for the observed stratigraphy in the EBS. Even when extension is

515 allowed to vary with depth, a relatively depth-uniform stretching history is recovered by

516 inversion for both Cases 1 and 2 (Figs. 4 and 5). A slight broadening of the strain rate

517 distribution with depth is recovered in the center of the basin, while a more pronounced increase

518 in strain rate with depth is associated with Sinop Trough. However, these variations in stretching

519 with depth are mild in comparison with those inferred for other basins (Edwards, 2006; Edwards

520 et al., in prep). Furthermore, depth-uniform and depth-dependent inversions produce similarly

521 good matches between predicted and observed horizons (Table 1). Therefore, we consider the 
522 central basin of the eastern Black Sea to have formed predominantly by depth-uniform

523 stretching. This study is the first time to our knowledge that a modeling algorithm that allows for

524 any style of depth-dependent stretching has been applied to produce a relatively depth-uniform

525 result.

\section{$526 \quad$ 8.6 Along-strike variations in extension in the EBS}

To investigate possible changes in the amount of extension along strike in the EBS, we

528 estimate $\beta$ throughout the EBS using a relationship between $\beta$ and sediment thickness derived

529 from strain rate inversion results for PWD Case 1 (see inset in Fig. 9). This map was then filtered

530 at $40 \mathrm{~km}$ to highlight regional trends and remove small-scale variations from individual faults.

531 The result implies a first-order increase in extension to the east, which is illustrated by the

532 increasing size of regions with $\beta>5$ in this direction (Fig. 9). This overall trend is interrupted by

533 intervening regions with lower apparent $\beta$ values; these most likely arise from a series of NE-SW

534 trending faults that offset the basement in the eastern basin (Finetti et al., 1988). This apparent

535 eastward increase in the amount of extension is consistent with the idea that the EBS opened by

536 rotation of the Shatsky Ridge away from the Mid Black Sea High (Fig. 1) (Okay et al., 1994),

537 where the increasing distance between the Shatsky Ridge and Mid Black Sea High should be

538 accompanied by increased $\beta$ values.

\section{9. Conclusions and Implications}

540 The analysis presented here yields the following major results: 1) very little depth-

541 dependence is required to explain the observed stratigraphy in the EBS, and a largely depth-

542 uniform model is recovered by inversion even when depth-dependent stretching is permitted; 2)

543 extension in the EBS most likely continued into the early Cenozoic, consistent with stratigraphic

544 relationships and observations from onshore mapping; 3) subsidence analysis also identifies a 
545 later subsidence anomaly (15-10 Ma) that is most pronounced in the northeastern part of the

546 basin, which is likely related to shortening from northward movement of Arabian plate.

\section{Acknowledgements}

$548 \quad$ This work was supported by the Natural Environment Research Council (UK)

549 (NER/T/S/2003/00114 and NER/T/S/2003/00885), BP and the Turkish Petroleum Company

550 (TPAO). BP and TPAO generously provided access to the seismic reflection and well-log data

551 that underpin this study. We would particularly like to thank G. Coskun (TPAO), A. Demirer

552 (TPAO), A.J. Haines (Cambridge), R. O’Connor (BP), B. Peterson (BP), A. Price (BP), and K.

553 Raven (BP) for their help. We would also like to thank A.H.F. Robertson for useful discussions.

554 Constructive suggestions and reviews by S. Cloetingh, R. van der Hilst and an anonymous

555 reviewer substantially improved the manuscript. University of Cambridge Department of Earth

556 Sciences Contribution Number ES 8977.

557

558

559 


\section{Appendix: Stratigraphy}

561

562

563

564

565

566

\section{Upper Jurassic-Upper Cretaceous}

Drilling at the margins of the Black Sea and mapping of time-correlative units onshore (e.g., Kapanbogazi and Inalti Fms) indicates that Upper Jurassic through Upper Cretaceous sedimentary rocks are comprised of a variety of lithologies, notably including shallow water carbonate rocks. Sections from this time period also contain significant volcanic material (Robinson et al., 1995a; Görür and Tüysüz, 1997). Carbonate rocks and chalks of this age have been drilled at Chaladidi-13, Chaladidi-14, Ochamchira and Akcakoca (Fig. 1) (Robinson et al., 1996; Banks et al., 1997). The Upper Cretaceous section exposed onshore south of Sinop is comprised of reefal limestone (Boyabat Limestone) and calciturbidites and limestones (Akveren Fm.) (Görür and Tüysüz, 1997).

\section{Early Paleocene - Middle Eocene (45-65 Ma)}

Time-correlative formations exposed in the western and eastern Pontides (Atbasi and Kusuri Fms.) are dominantly siliclastic turbidites, shallow and/or deep water mudstones, pelagic limestones and marls, often containing significant amounts of volcanogenic sediments (Robinson et al., 1995b; Görür and Tüysüz, 1997; Yilmaz et al., 1997). Similar lithologies were encountered by drilling onshore in Georgia (Chaladidi-13 and Chaladidi-14) (Banks et al., 1997).

The characteristics of this interval in seismic sections implies that they were deposited as pelagic muds (Robinson et al., 1995a). However, information on this interval of EBS stratigraphy is limited due to its scant exposure onshore and in wells (Robinson et al., 1995b).

\section{Middle Eocene - Top of Eocene (45-33.9 Ma)}

Eocene formations exposed in the Pontides (Kusuri and Ayancik Fms.) are dominantly siliclastic turbidites (sandstones and shales) (Görür and Tüysüz, 1997; Yilmaz et al., 1997), and 
583 siliclastic turbidites and limestones were drilled onshore in Georgia (Chaladidi-13 and Chaladidi-

584 14) (Banks et al., 1997). Carbonate, terrigenous deposits were also encountered in this interval

585 offshore Bulgaria (Zonenshain and Le Pichon, 1986).

586 Maikop Formation: Top of Eocene - Early Miocene (33.9-20.5 Ma)

587 This stratigraphic unit comprises the most significant hydrocarbon source rock in the

588 Black Sea and Caspian regions. The deposition of muds rich in organic carbon is attributed to

589 anoxic conditions, and very little sand is observed in the Maikop Formation where it has been

590 sampled offshore (Robinson et al., 1996). Furthermore, the seismic transparency observed

591 within this unit in seismic reflection profiles suggests a homogeneity in physical properties

592 (Zonenshain and Le Pichon, 1986).

593 Early Miocene - Middle Miocene (Base of Sarmatian) (20.5-13 Ma)

594 Exploration wells on the Crimean peninsula and offshore Romania recovered mudstones

595 in this interval (Robinson et al., 1995a; Spandini et al., 1996; Meredith and Egan, 2002; Nikishin

596 et al., 2003). Correlative units exposed onshore provide little information as they are fluvial,

597 evaporitic or volcanic, and are thus unlikely to be representative of their equivalents in the basin

598 center (Robinson et al., 1995a). Parallel reflections observed in seismic reflection sections imply

599 turbiditic sediments in this interval (Zonenshain and Le Pichon, 1986; Robinson et al., 1995a).

600 Middle Miocene (Base of Sarmatian) - Late Miocene (Top of Sarmatian) (13-11 Ma)

601 This interval is thought to comprise terrigenous sediments, passively infilling the basin

602 center (Nikishin et al., 2003). Onshore exposures in Georgia are primarily sandy clastics (Banks

603 et al., 1997)

604 Late Miocene (Top of Sarmatian) - Top of Pliocene (11-1.8 Ma) 
60613 and Chaladidi-14) and mapped in northeastern Turkey (Robinson et al., 1995b), though these

607 units are typically non-marine and unlikely to be representative of lithologies in the basin center.

608 Chalks, siderites, clays and limestone were recovered by DSDP drilling in the basin center (Ross,

609 1978; Hsü and Giovanoli, 1980). Interestingly, this interval also contains a thin unit comprising

610 algal mats and peletal limestones, indicative of very shallow water depths (Ross, 1978; Hsü and

611 Giovanoli, 1980; Kojumdgieva, 1983). Although interpretations regarding the age and causes of

612 these deposits are controversial (Ross, 1978; Hsü and Giovanoli, 1980; Kojumdgieva, 1983), it

613 appears that they correspond to a drop in sea level of over $2000 \mathrm{~m}$, possibly related to Messinian

614 desiccation event that affected the entire Mediterranean region (Hsü et al., 1973). Because this

615 desiccation was likely short-lived (100 kyr) (Hsü and Giovanoli, 1980), it is not included in the

616 subsidence analysis presented in this paper.

\section{Top of Pliocene-Present (1.8-0 Ma)}

618 The youngest sediments in the Black Sea have been recovered by gravity cores and

619 drilling (Ross, 1978; Robinson et al., 1996; Aksu et al., 2002). Samples recovered at these

620 locations consistently demonstrate that the uppermost sediments contain mostly clays, although

621 they also include marls and occasional turbidites (Ross, 1978; Hsü and Giovanoli, 1980; Aksu et

622 al., 2002; Hiscott and Aksu, 2002). Likewise, high-resolution seismic and sonar images also

623 show primarily flat-lying, undisturbed sediments in the basin center, although the shallowest

624 sediments do show occasional disruption by gas (Ergün et al., 2002). 
626

627

628

629

630

631

632

633

634

635

636

637

638

639

640

641

642

643

644

645

646

647

648

649

650

651

652

653

654

655

656

657

658

659

660

661

662

663

664

665

666

667

668

669

Aksu, A. E., R. N. Hiscott, D. Yasar, F. I. Isler, and S. Marsh, 2002, Seismic stratigraphy of the Late Quatenary deposits from the southwestern Black Sea shelf: evidence for noncatastrophic variations in sea-level during the last $\sim 10000$ yr: Marine Geology, v. 190, p. 61-94.

Al-Lazki, A. I., E. Sandvol, D. Seber, M. Barazangi, N. Turkelli, and R. Mohamad, 2004, Pn tomographic imaging of mantle lid velocity and anisotropy at the junction of the Arabian, Eurasian and African plates: Geophys. J. Int., v. 158, p. 1024-1040.

Banks, C. J., A. G. Robinson, and M. P. Williams, 1997, Structure and regional tectonics of the Achara-Trialet fold belt and the adjacent Rioni and Kartli foreland basins: AAPG Memoir 68: Tulsa, OK, AAPG.

Bellingham, P., and N. White, 2002, A two-dimensional inverse model for extensional sedimentary basins: 2. Application: J. Geophys. Res., v. 107, doi:10.1029/2001JB000174.

Belousov, V. V., B. S. Volvovsky, I. V. Arkhipov, V. B. Buryanova, Y. D. Evsyukov, V. P. Goncharov, V. V. Gordienko, D. F. Ismagilov, G. K. Kislov, L. I. Kogan, V. N. Moskalenko, Y. P. Neprchnov, B. K. Ostisty, O. M. Rusakov, K. M. Shimkus, A. E. Shlenzinger, V. V. Sochelnikov, V. B. Sollogub, V. D. Solovyev, V. I. Starostenko, A. F. Starovoitov, A. A. Terekhov, I. S. Volvovsky, A. S. Zhigunov, and V. G. Zolotarev, 1988, Structure and evolution of the earth's crust and upper mantle of the Black Sea: Bollettino Di Geofisica Teorica ed Applicata, v. 30 p. 109-196.

Boztug, D., R. Jonckheere, G. A. Wagner, and Z. Yegingil, 2004, Slow Senonian and fast Palaeocene-Early Eocene uplift of the granitoids in the Central Eastern Pontides, Turkey: apatite fission-track results: Tectonophysics, v. 382, p. 213-228.

Bry, M., and N. White, 2007, Reappraising elastic thickness variation at oceanic trenches: J. Geophys. Res., v. 112, doi:10.1029/2005JB004190.

Buck, W. R., F. Martinez, M. S. Steckler, and J. R. Cochran, 1988, Thermal Consequences of Lithospheric Extension: Pure and Simple: Tectonics, v. 7, p. 213-234.

Burov, E. B., and M. Diament, 1995, The effective elastic thickness $(\mathrm{Te})$ of continental lithosphere: What does it really mean?: J. Geophys. Res., v. 100, p. 3905-3927.

Çakir, Ö., and M. Erduran, 2004, Constraining crustal and uppermost mantle structures beneath station TBZ (Trabzon, Turkey) by receiver functions and dispersion analysis: Geophys. J. Int., v. 158, p. 955-971.

Cloetingh, S., G. Spandini, J. D. Van Wees, and F. Beekman, 2003, Thermo-mechanical modelling of the Black Sea Basin (de)formation: Sedimentary Geology, v. 156, p. 169184.

Davis, M., and N. Kusznir, 2004, Depth-Dependent Lithospheric Stretching at Rifted Continental Margins, in G. D. Karner, J. D. Morris, N. W. Driscoll, and E. A. Silver, eds., Rheology and Deformation of the Lithosphere: New York, NY, Columbia University Press, p. 92137.

Edwards, G. R. H., 2006, Inverse Modelling of Extensional Sedimentary Basins and Margins: Doctoral thesis, University of Cambridge, Cambridge, $226 \mathrm{p}$.

Edwards, G. R. H., N. White, and J. Haines, in prep, Inverse modelling of extensional sedimentary basins and margins: J. Geophys. Res.

Ergün, M., D. Dondurur, and G. Cifci, 2002, Acoustic evidence for shallow gas accumulations in the sediments of the Eastern Black Sea: Terra Nova, v. 14, p. 313-320. 
Finetti, I., G. Bricchi, A. Del Ben, M. Pipan, and Z. Xuan, 1988, Geophysical Study of the Black Sea: Bollettino Di Geofisica Teorica ed Applicata, v. XXX, p. 197-324.

Gök, R., E. Sandvol, N. Türkelli, D. Seber, and M. Barazangi, 2003, Sn attenuation in the Anatolian and Iranian plateau and surrounding regions: Geophys. Res. Lett., v. 30, 8042, doi:10.1029/2003GL018020.

Görür, N., 1988, Timing of opening of the Black Sea basin: Tectonophysics, v. 147, p. 247-262.

Görür, N., and O. Tüysüz, 1997, Petroleum Geology of the Southern Continental Margin of the Black Sea, in A. G. Robinson, ed., Regional and petroleum geology of the Black Sea and surrounding region: AAPG Memoir, v. 68: Tulsa, OK, AAPG, p. 241-254.

Gradstein, F. M., J. G. Ogg, A. G. Smith, and e. al., 2004, A Geologic Time Scale 2004: Cambridge, Cambridge University Press.

Hearn, T. M., and J. F. Ni, 1994, Pn velocities beneath continental collision zones: the TurkishIranian Plateau: Geophys. J. Int., v. 117, p. 273-283.

Hiscott, R. N., and A. E. Aksu, 2002, Late Quaternary history of the Marmara Sea and Black Sea from high-resolution seismic and gravity-core studies: Marine Geology, v. 190, p. 261282.

Hopper, J. R., and W. R. Buck, 1998, Styles of extensional decoupling: Geology, v. 26, p. 699702.

Hsü, K. J., and F. Giovanoli, 1980, Messian event in the Black Sea: Palaeogeography, Palaeoclimatology, Palaeoecology, v. 29, p. 75-83.

Hsü, K. J., W. B. F. Ryan, and M. B. Cita, 1973, Late Miocene desiccation of the Mediterranean: Nature, v. 242, p. 240-244.

IOC IHO BODC, 2003, Centenary Edition of the GEBCO Digital Atlas, published on CD-ROM on behalf of the Intergovernmental Oceaonographic Commission and the International Hydrographic Organization as part of the General Bathymetric Chart of the Oceans, Liverpool, British Oceanographic Data Centre.

Jones, R. W., and M. D. Simmons, 1997, A Review of the Stratigraphy of Eastern Paratethys (Oligocene-Holocene), With Particular Emphasis on th Black Sea, in A. G. Robinson, ed., Regional and petroleum geology of the Black Sea and surrounding region, v. 68, AAPG Memoir, p. 39-52.

Jones, S. M., N. White, P. Faulkner, and P. Bellingham, 2004, Animated models of extensional basins and passive margins: Geochem. Geophys. Geosyst., v. 5, Q08009, doi:10.1029/2003GC000658.

Kazmin, V. G., A. A. Schreider, and A. A. Bulychev, 2000, Early stages of evolution of the Black Sea, in E. Bozkurt, J. A. Winchester, and J. D. A. Piper, eds., Tectonics and Magmatism in Turkey and the Surrounding Area, v. Special Publications, 173: London, Geological Society, p. 235-249.

Kojumdgieva, E., 1983, Palaeogeographic Environment During the Desiccation of the Black Sea: Palaeogeography, Palaeoclimatology, Palaeoecology, v. 43, p. 195-204.

Kutas, R. I., V. P. Kobolev, and V. A. Tsvyashchenko, 1998, Heat flow and geothermal model of the Black Sea depression: Tectonophysics, v. 291, p. 91-100.

Lavier, L. L., and G. Manatschal, 2006, A mechanism to thin the continental lithosphere at magma-poor margins: Nature, v. 440, p. 324-328.

Letouzey, J., B. Biju-Duval, A. Dorkel, R. Gonnard, K. Kristchev, L. Montadert, and O. Sungurlu, 1977, The Black Sea: A Marginal Basin, Geophysical and Geological Data, in 
B. Biju-Duval, and L. Montadert, eds., International Symposium of the Mediterranean Basins Split (Yugoslavia) 25-29 October 1976: Paris, Editions Technip, p. 363-376.

McClusky, S., S. Balassanian, A. Barka, C. Demir, S. Ergintav, G. Georgiev, O. Gurkan, M. Hamburger, K. Hurst, H. Kahle, K. Kastens, G. Kekelidze, R. King, V. Kotzev, O. Lenk, S. Mahmoud, A. Mishin, M. Ndariya, A. Ouzounis, D. Paradissis, Y. Peter, M. Prilepin, R. Reilinger, I. Sanli, H. Seeger, A. Tealeb, M. N. Toksöz, and G. Veis, 2000, Global Positioning System constraints on plate kinematics and dynamics in the eastern Mediterranean and Caucaus: J. Geophys. Res., v. 105, p. 5695-5719.

McKenzie, D., 1972, Active tectonics of the Mediterranean Region: Geophys. J. R. astr. Soc., v. 30, p. 109-185.

McKenzie, D., and D. Fairhead, 1997, Estimates of the effective elastic thickness of the continental lithosphere from Bouguer and free air gravity anomalies: J. Geophys. Res., v. 102 , p. 27,523-27,552.

McKenzie, D., F. Nimmo, J. A. Jackson, P. B. Gans, and E. L. Miller, 2000, Characteristics and consequences of flow in the lower crust: J. Geophys. Res., v. 105, p. 11,029-11,046.

McKenzie, D. P., 1978, Some remarks on the development of sedimentary basins: Earth Planet. Sci. Lett., v. 40, p. 25-32.

Meredith, D. J., and S. S. Egan, 2002, The geological and geodynamic evolution of the eastern Black Sea basin: insights from 2-D and 3-D tectonic modelling: Tectonophysics, v. 350, p. $157-179$.

Minshull, T. A., N. J. White, R. A. Edwards, D. J. Shillington, C. L. Scott, A. Demirer, M. Shaw-Champion, S. M. Jones, M. Erduran, T. Beselvi, G. Coskun, K. Raven, A. Price, and B. Peterson, 2005, Seismic Data Reveal Eastern Black Sea Structure: Eos, v. 86, p. 413,416-7.

Nikishin, A. M., M. V. Korotaev, A. V. Ershov, and M.-F. Brunet, 2003, The Black Sea basin: tectonic history and Neogene-Quaternary rapid subsidence modelling: Sedimentary Geology, v. 156, p. 149-168.

Okay, A. I., A. M. C. Sengor, and N. Görür, 1994, Kinematic history of the opening of the Black Sea and its effect on the surrounding regions: Geology, v. 22, p. 267-270.

Parsons, B., and J. G. Sclater, 1977, An Analysis of the Variation in Ocean Floor Bathymetry and Heat Flow with Age: J. Geophys. Res., v. 82, p. 803-827.

Perez-Gussinye, M., A. R. Lowry, A. B. Watts, and I. Velicogna, 2004, On the recovery of effective elastic thickness using spectral methods: Examples from synthetic data and from the Fennoscandia Shield: J. Geophys. Res., v. 109, doi: 10.1029/2003JB002788.

Press, W. H., S. A. Teukolsky, W. T. Vetterling, and B. P. Flannery, 1992, Numerical Recipes in Fortran 77: the art of scientific computing: Cambridge, Cambridge University Press.

Rangin, C., A. G. Bader, G. Pascal, B. Ecevitoglu, and N. Görür, 2002, Deep structure of the Mid Black Sea High (offshore Turkey) imaged by multi-channel seismic survey (BLACKSIS cruise): Marine Geology, v. 182, p. 265-278.

Reilinger, R., S. McClusky, P. Vernant, S. Lawrence, S. Ergintav, R. Cakmak, H. Ozener, F. Kadirov, I. Guliev, R. Stepanyan, M. Nadariya, G. Hahubia, S. Mahmoud, K. Sakr, A. ArRajehi, D. Paradissis, A. Al-Aydrus, M. Prilepin, T. Guseva, E. Evren, A. Dmitrotsa, S. V. Filikov, F. Gomez, R. Al-Ghazzi, and G. Karam, 2006, GPS constraints on continental deformation in the Africa-Arabia-Eurasia continental collision zone and implications for the dynamics of plate interactions: J. Geophys. Res., v. 111, doi:10.1029/2005JB004051. 
803

804

Robertson, A. H. F., T. Ustaömer, E. A. Pickett, A. S. Collins, T. Andrew, and J. E. Dixon, 2004, Testing models of Late-Palaeozoic-Early Mesozoic orogeny in Western Turkey: support for an evolving open-Tethys model: J. Geol. Soc. London, v. 161, p. 501-511.

Robinson, A., G. Spandini, S. Cloetingh, and J. Rudat, 1995a, Stratigraphic Evolution of the Black Sea: inferences from basin modelling: Marine Pet. Geol., v. 12, p. 831-835.

Robinson, A. G., C. J. Banks, M. M. Rutherford, and J. P. P. Hirst, 1995b, Stratigraphic and structural development of the Eastern Pontides, Turkey: J. Geol. Soc. London, v. 152, p. 861-872.

Robinson, A. G., J. H. Rudat, C. J. Banks, and R. L. F. Wiles, 1996, Petroleum Geology of the Black Sea: Marine Petrol. Geol., v. 13, p. 195-223.

Ross, D. A., 1978, Summary of results of Black Sea drilling, Init. Rep. DSDP, v. 42, p. 11491177.

Ross, D. A., Y. P. Neprchnov, K. J. Hsu, E. S. Trimonis, S. F. Percival, Jr., A. J. Erickson, E. T. Degens, J. M. Hunt, F. T. Manheim, M. Senalp, A. Traverse, and P. Stoffers, 1978, Leg 42, Part 2, of the cruises of the drilling vessel Glomar Challenger; Istanbul, Turkey to Istanbul, Turkey, May-June 1975, DSDP.

Rudat, J. H., and D. S. Macgregor, 1993, Unconventional exploration techniques in a high cost deep water basin: a case study from the Black Sea: Soc. of Explor. Geophys. Abstr. Progr.

Saintot, A., and J. Angelier, 2002, Tectonic paleostress fields and structural evolution of the NW-Caucaus fold-and-thrust belt from Late Cretaceous to Quaternary: Tectonophysics, v. 357, p. 1-31.

Sclater, J. G., and P. A. F. Christie, 1980, Continental Stretching: An Explanation of the PostMid-Cretaceous Subsidence of the Central North Sea Basin: J. Geophys. Res., v. 85, p. 3711-3739.

Spandini, G., A. Robinson, and S. Cloetingh, 1996, Western versus Eastern Black Sea tectonic evolution: pre-rift lithospheric controls on basin formation: Tectonophysics, v. 266, p. 139-154.

Spandini, G., A. G. Robinson, and S. A. P. L. Cloetingh, 1997, Thermomechanical Modeling of Black Sea Basin Formation, Subsidence and Sedimentation, in A. G. Robinson, ed., Regional and petroleum geology of the Black Sea and surrounding region, v. 68: Tulsa, AAPG Memoir, p. 19-38.

Starostenko, V., V. Buryanov, I. Makarenko, O. Rusakov, R. Stephenson, A. Nikishin, G. Georgiev, M. Gerasimov, R. Dimitriu, O. Legostaeva, V. Pchelarov, and C. Sava, 2004, Topography of the crust-mantle boundary beneath the Black Sea Basin: Tectonophysics, v. 381, p. 211-233.

Steckler, M. S., and A. B. Watts, 1978, Subsidence of the Atlantic-type Continental Margin off New York: Earth Planet. Sci. Lett., v. 41, p. 1-13.

Turcotte, D. L., and G. Schubert, 2002, Geodynamics: Cambridge, UK, Cambridge University Press.

Ustaömer, T., and A. H. F. Robertson, 1997, Tectonic-Sedimentary Evolution of the North Tethyan Margin in the Central Pontides of Northern Turkey, in A. G. Robinson, ed., Regional and petroleum geology of the Black Sea and surrounding regions: AAPG Memoir 68: Tulsa, OK, AAPG, p. 255-290. 
Vincent, S. J., M. B. Allen, A. D. Ismail-Zadeh, R. Flecker, K. A. Foland, and M. D. Simmons, 2005, Insights from the Talysh of Azerbaijan into the Paleogene evolution of the South Caspian region: GSA Bulletin, v. 117, p. 1513-1533.

Wernicke, B., 1985, Uniform-sense of normal sense simple-shear of the continental lithosphere: Can. J. Earth Sci., v. 22, p. 108-125.

White, N., 1993, Recovery of strain rate variation from inversion of subsidence data: Nature, v. 366, p. 449-452.

White, N., and P. Bellingham, 2002, A two-dimensional inverse model for extensional sedimentary basins: 1. Theory: J. Geophys. Res., v. 107, p. doi: 10.1029/2001JB000173.

Whitmarsh, R. B., G. Manatschal, and T. A. Minshull, 2001, Evolution of magma-poor continental margins from rifting to seafloor spreading: Nature, v. 413, p. 150-153.

Yilmaz, Y., O. Tüysüz, E. Yigitbas, S. Genç, Can, and A. M. C. Sengör, 1997, Geology and Tectonic Evolution of the Pontides, in A. G. Robinson, ed., Regional and petroleum geology of the Black Sea and surrounding region: AAPG Memoir 68: Tulsa, AAPG, p. 183-226.

Zonenshain, L. P., and X. Le Pichon, 1986, Deep Basins of the Black Sea and Caspian Sea as Remnants of Mesozoic Back-Arc Basins: Tectonophysics, v. 123, p. 181-211.

Zor, E., E. Sandvol, C. Gürbüz, N. Türkelli, D. Seber, and M. Barazangi, 2003, The crustal structure of the East Anatolian plateau (Turkey) from receiver functions: Geophys. Res. Lett., v. 30, p. 8044. 
829 Figure 1. Map of the eastern Black Sea showing Cenozoic sediment thickness in the center of

830 the basin and illuminated elevation from GEBCO (IOC IHO BODC, 2003) outside the basin.

831 Sediment thickness is estimated from seismic reflection profiles. The transect used for

832 subsidence analysis is indicated with a black line. Other major features are also labeled and

833 discussed further in Sections 2-4. White circles indicate earthquakes with magnitudes $>3$ that

834 occurred from Aug. 2005 - Aug. 2006 and are scaled by magnitude; these were taken from the

835 online catalogue of the Centre Sismologique Euro-Méditerranéen. The inset in the upper right

836 hand corner gives the location of the study area with respect to the entire Black Sea and shows

837 the locations of academic and industry wells around the Black Sea that are discussed in the text.

839 Figure 2. a. Seismic reflection profiles KDZ 91-43 and 8040 (Robinson et al., 1996), which

840 correspond with the subsidence analysis along the profile whose location is shown in Fig. 1. The

841 inset shows the depth-time relationship derived from stacking velocities, which was used to

842 convert seismic stratigraphic horizons to depth. The black line indicates depth-time function in

843 the center of the basin averaged over $150 \mathrm{~km}$, and grey shading indicates $+/$ - one standard

844 deviation. b. Interpreted section showing the horizons and ages used for subsidence analysis and 845 other major features observed on these lines.

847 Figure 3. Stratigraphic column from the center of the eastern Black Sea estimated from onshore 848 geologic mapping, existing well control and seismic reflection data, which are described in the 849 Appendix. Three different cases of paleowater depth (PWD) variations are shown in the third to 
850 fifth columns; each of these is modeled during strain rate inversion to address uncertainties in

851 this parameter. In each case, the depth shown is the depth in the deepest part of the basin. The

852 sixth column shows the PWD estimates/assumptions employed in previous studies (Robinson et

853 al., 1995a; Meredith and Egan, 2002; Cloetingh et al., 2003; Nikishin et al., 2003). Note that our

854 three PWD cases encompass many of the variations inferred or estimated by previous studies.

855 Estimated ages for each horizon are taken from previous work. Tectonic events in the right

856 column are taken from Boztug et al. (Boztug et al., 2004) and Saintot et al. (Saintot and Angelier, 857 2002).

859 Figure 4. Results from both depth-uniform (left column) and depth-dependent strain rate 860 inversion (middle and right columns) for the PWD Case 1 assuming Airy isostasy. Illustrated in

861 Figure 3 and described in Section 7.1. The upper panels show the match between flexurally

862 backstripped stratigraphic horizons that served as input (black lines) and model predictions (red

863 dashed lines). For the depth-uniform model, the middle panel is a grid showing spatial and

864 temporal variations in strain rate. The lower panel shows cumulative beta at each time step

865 (black lines) and beta calculated from preliminary velocity model from wide-angle seismic

866 refraction data (dashed grey line) (Minshull et al., 2005). The four panels in the middle and right

867 columns are orthogonal slices through strain rate cube produced by depth-dependent inversion.

868 The panels in the middle column are depth slices at $0 \mathrm{~km}$ depth (which can be compared with 869 depth-uniform result) and $120 \mathrm{~km}$ depth. The right panels are time slices at $58.5 \mathrm{Ma}$ and $13 \mathrm{Ma}$. 
871 Figure 5. Results from both depth-uniform (left column) and depth-dependent strain rate

872 inversion (middle and right columns) for the PWD Case 2 assuming Airy isostasy. Illustrated in

873 Figure 3 and described in Section 7.2. See Figure 4 caption for explanation of panels.

874

875 Figure 6. Results from both depth-uniform (left column) and depth-dependent strain rate

876 inversion (middle and right columns) for the PWD Case 3 assuming Airy isostasy. Illustrated in

877 Figure 3 and described in Section 7.3. See Figure 4 caption for explanation of panels.

878

879 Figure 7. a. Results of pure-shear strain rate inversion using PWD Case 1 and different values for

$880 T_{e}(0,20,50,100 \mathrm{~km})$. Notice that larger strain rates and stretching factors are recovered by

881 inversion when larger values for $T_{e}$ are used. b. Results of strain rate inversion using PWD Case

8822 and different values for $T_{e}$. c. Misfit as a function of $T_{e}$ for PWD Cases 1 and 2. d. Match

883 between predicted curvature of Shatsky Ridge for various values of $T_{e}$ based on a pointed-loaded

884 broken elastic beam (dotted blue lines) and average of curvature of Shatsky Ridge over $40 \mathrm{~km}$

885 along strike (black line). Grey shaded area indicates \pm 1 standard deviation of averaged profiles

886 and serves as the uncertainty for $T_{e}$ estimation. Inset shows misfit function; a $T_{e}$ of $2.3 \mathrm{~km}$ best

887 fits the data, and values of $T_{e}$ between $2-3 \mathrm{~km}$ fit data with a chi-squared of $<1$.

889 Figure 8. Possible examples of growth in reflection data from a. Sinop trough, line KDZ 91-43a;

890 b. center of the EBS, line 8037.

892 Figure 9. $\beta$ variations over entire eastern Black sea estimated from the relationship between

893 sediment thickness and $\beta$ for PWD Case 1. The large map shows contoured estimated $\beta$ over the 
894 EBS following spatial filtering of $40 \mathrm{~km}$. Dark shading indicates high $\beta$ values. The maximum

895 estimated $\beta$ in the basin is $\sim 5-6$. Regions with poor data coverage or that are strongly affected by

896 compression (e.g., around Tuapse trough) have been masked. The inset shows the relationship

897 between $\beta$ and sediment thickness based on subsidence analyses presented in Figure 4 . The black

898 line represents the best fitting polynominal, which was used to estimate $\beta$ across the basin. The

899 grey band indicates \pm 1 standard deviation.

900

901 Suppl. Figure Captions

902

903 Suppl. Figure 1. a. Input horizons along the profile following depth conversion. b. Input

904 horizons following backstripping assuming PWD for Case 1, where shallow PWD was

905 associated with the end of the Cretaceous $(0-200 \mathrm{~km})$, and deep PWD was present afterwards

$906(2000-2200 \mathrm{~m})$. Colored lines indicated results of backstripping using different values for $T_{e}(0$,

$90720,50,100 \mathrm{~km})$. c. Input horizons following backstripping assuming PWD for Case 2, where

908 deep PWD characterized the basin from the end of Cretaceous to the present. d. Input horizons

909 following backstripping assuming PWD for Case 3, where shallow PWD was associated with the

910 basin until the end of Pliocene times (0-200 m), and deep PWD was present afterwards.

911

912

913

914 
Table 1, Shillington et al.

\begin{tabular}{|c|c|c|c|c|c|}
\hline PWD Case & $\begin{array}{l}\text { Max. strain } \\
\text { rate } 65-45 \\
\operatorname{Ma}\left(m . y .^{-1}\right)\end{array}$ & $\begin{array}{l}\text { Max. strain } \\
\text { rate } 65-45 \\
M a\left(s^{-1}\right)\end{array}$ & $\begin{array}{l}\text { Max strain } \\
\text { rate 20-0 Ma } \\
\left(m . y^{-1}\right)\end{array}$ & $\begin{array}{l}\text { Max strain } \\
\text { rate 20-0 } \\
\operatorname{Ma}\left(s^{-1}\right)\end{array}$ & Chi-squared \\
\hline Case 1, depth-uniform & 0.0798 & $2.53 \times 10^{-15}$ & 0.0231 & $7.33 \times 10^{-16}$ & 2.089 \\
\hline Case 1 , depth-dependent & 0.0847 & $2.68 \times 10^{-15}$ & 0.0265 & $8.40 \times 10^{-16}$ & 0.860 \\
\hline Case 2, depth-uniform & 0.0147 & $4.66 \times 10^{-16}$ & 0.0301 & $9.55 \times 10^{-16}$ & 2.324 \\
\hline Case 2, depth-dependent & 0.0189 & $5.99 \times 10^{-16}$ & 0.0246 & $7.81 \times 10^{-16}$ & 0.859 \\
\hline Case 3, depth-uniform & 0.0433 & $1.37 \times 10^{-15}$ & 0.1781 & $5.65 \times 10^{-15}$ & 6.379 \\
\hline Case 3 , depth-dependent & 0.0423 & $1.34 \times 10^{-15}$ & 0.1868 & $5.92 \times 10^{-15}$ & 3.007 \\
\hline
\end{tabular}


Figure 1, Shillington et al.

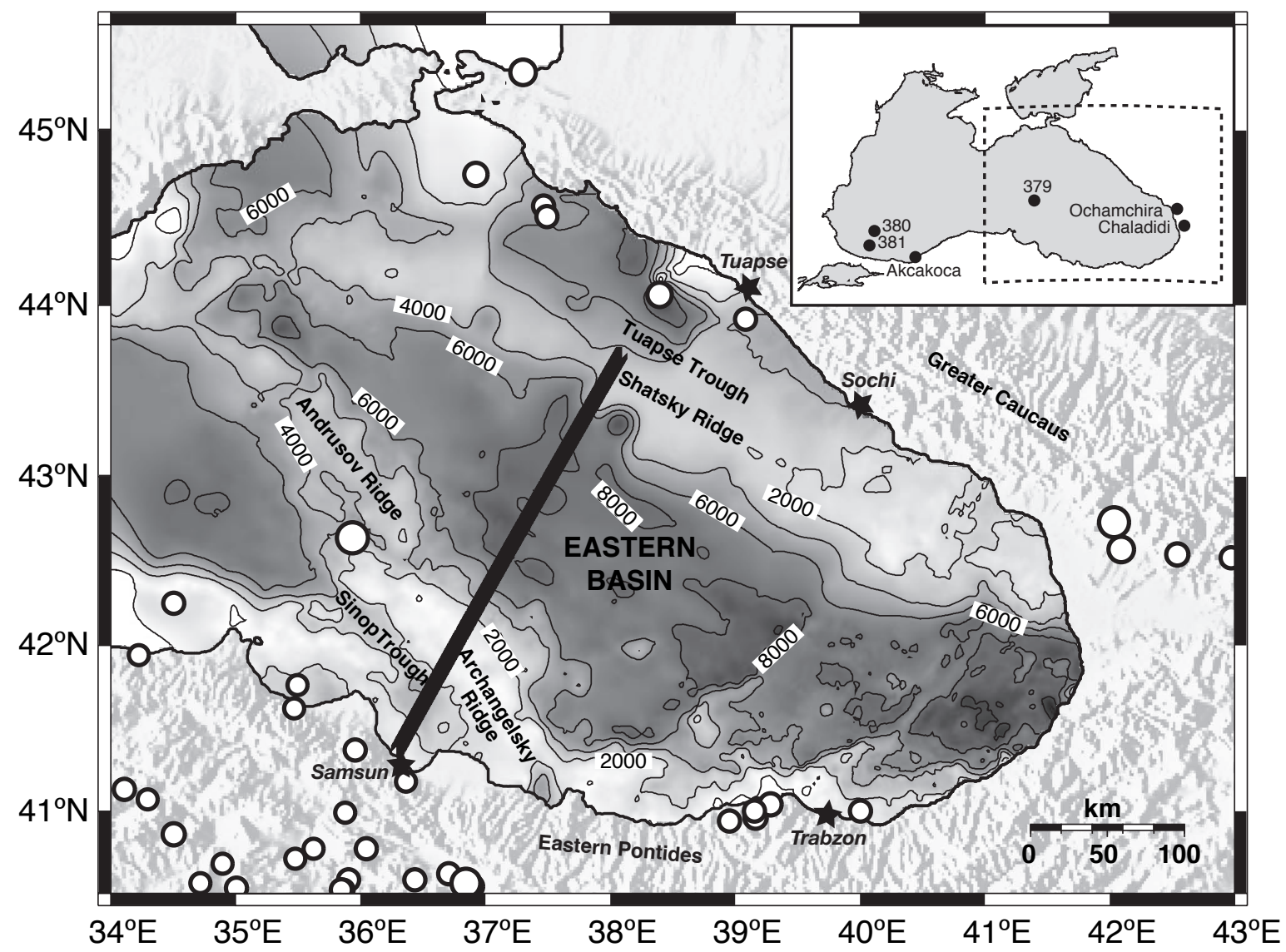


Figure 2, Shillington et al.
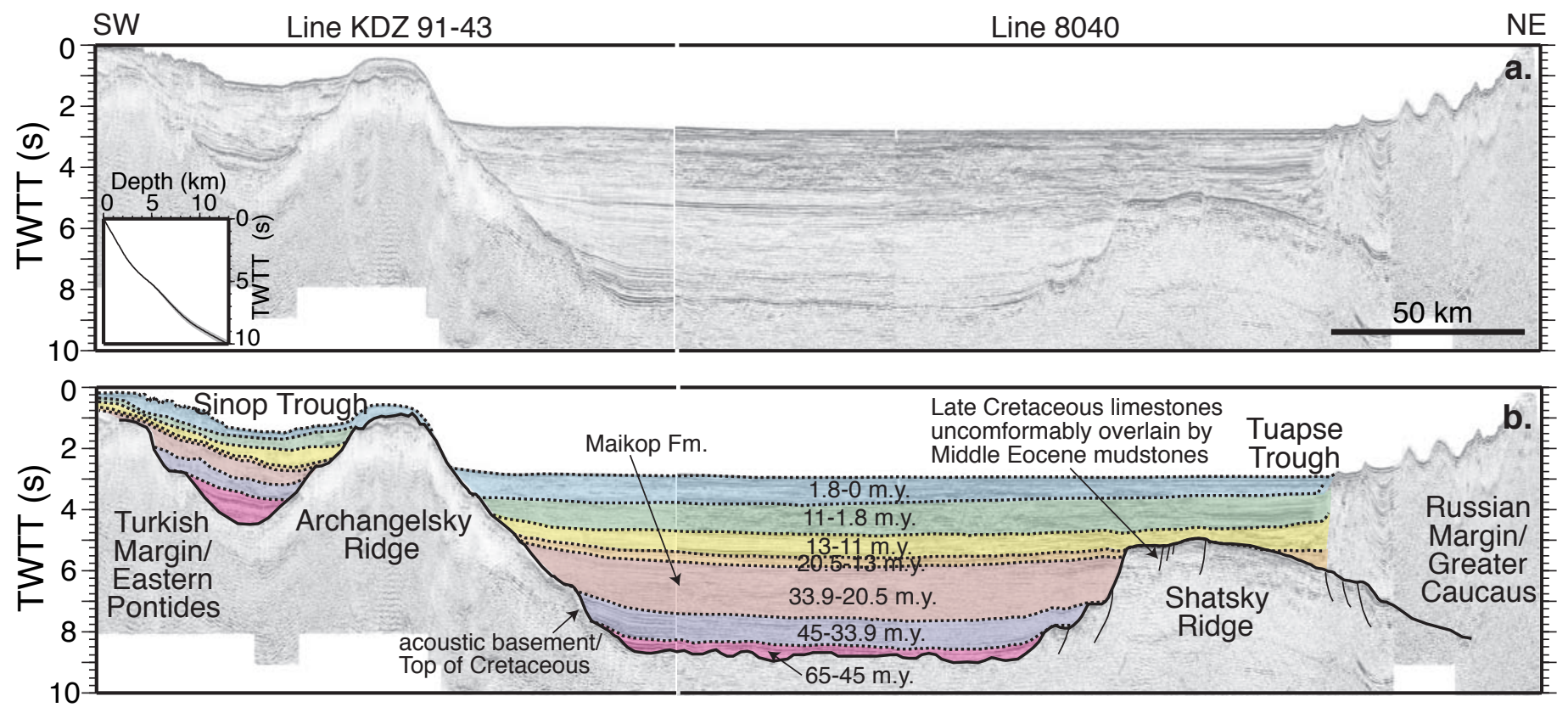
Figure 3, Shillington et al.

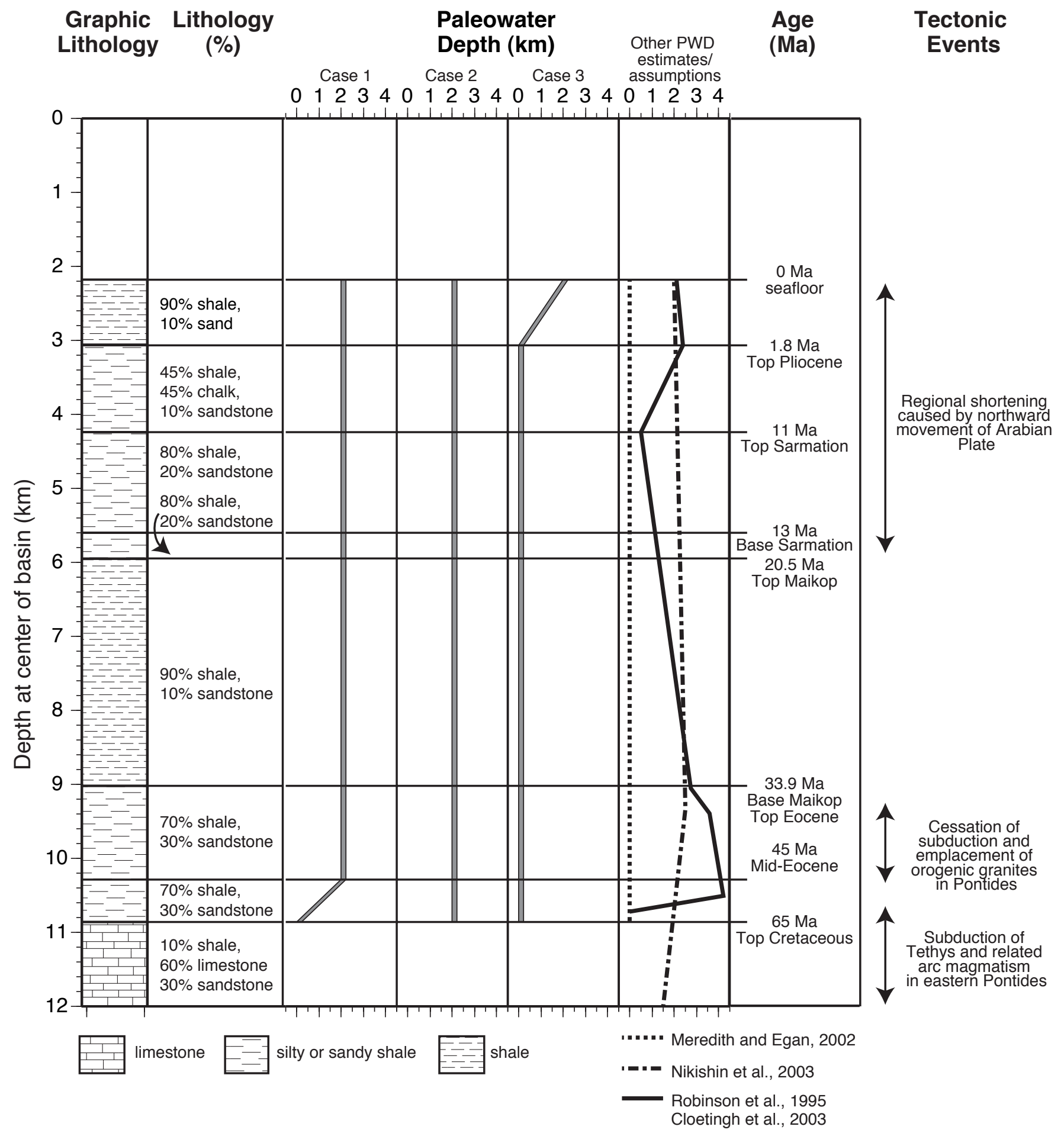


Figure 4, Shillington et al.
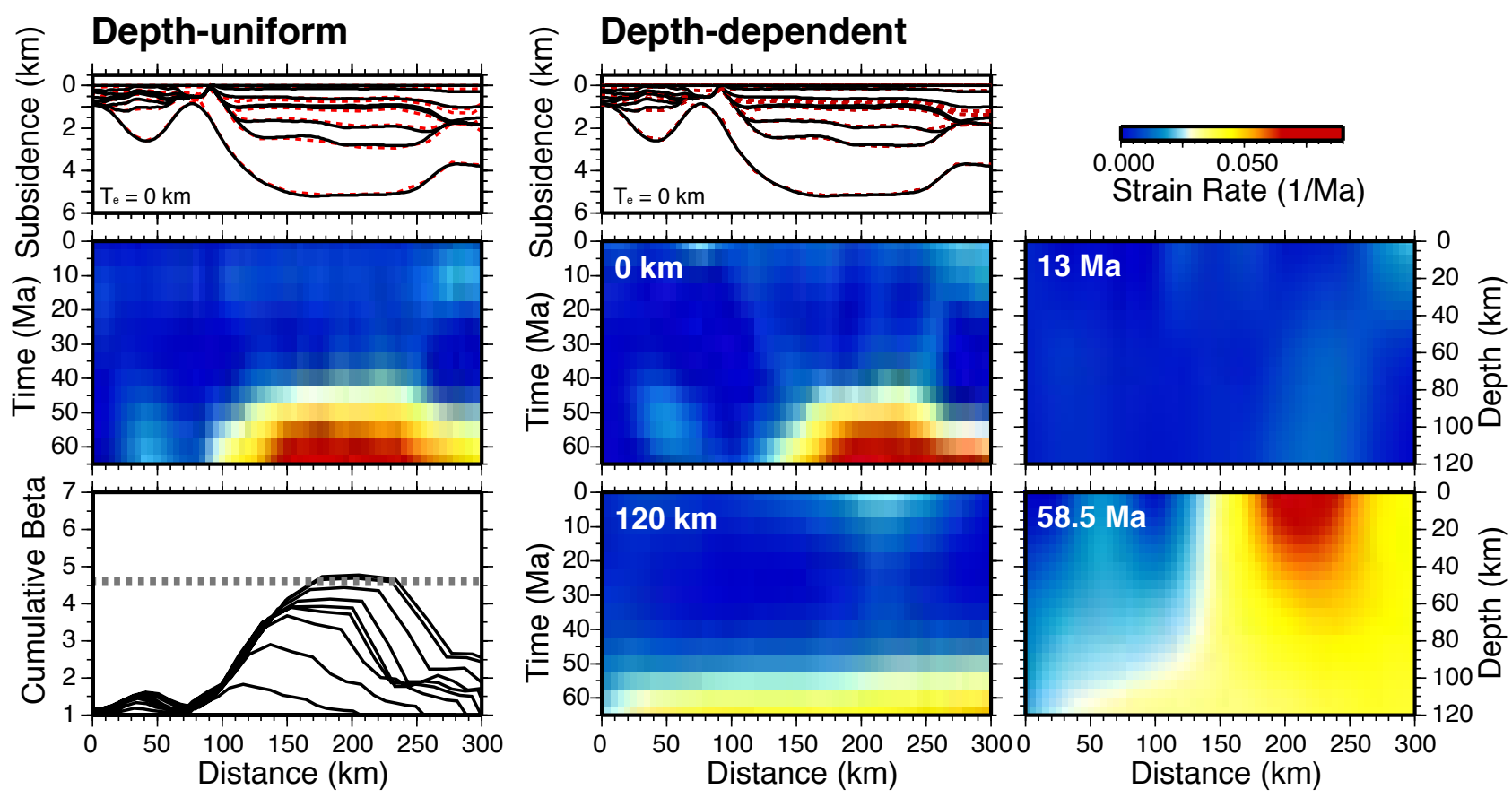
Figure 5, Shillington et al.
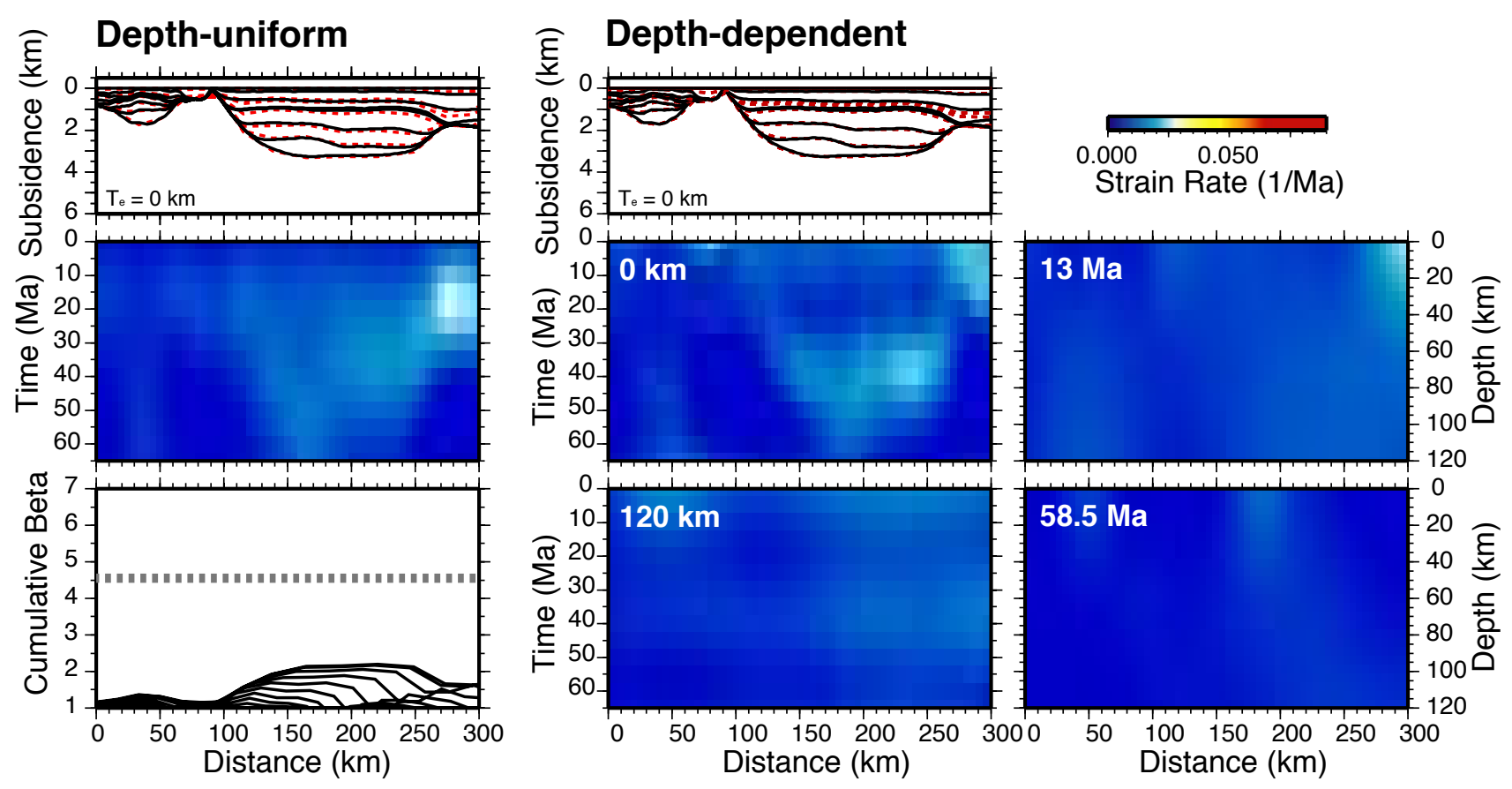
Figure 6, Shillington et al.
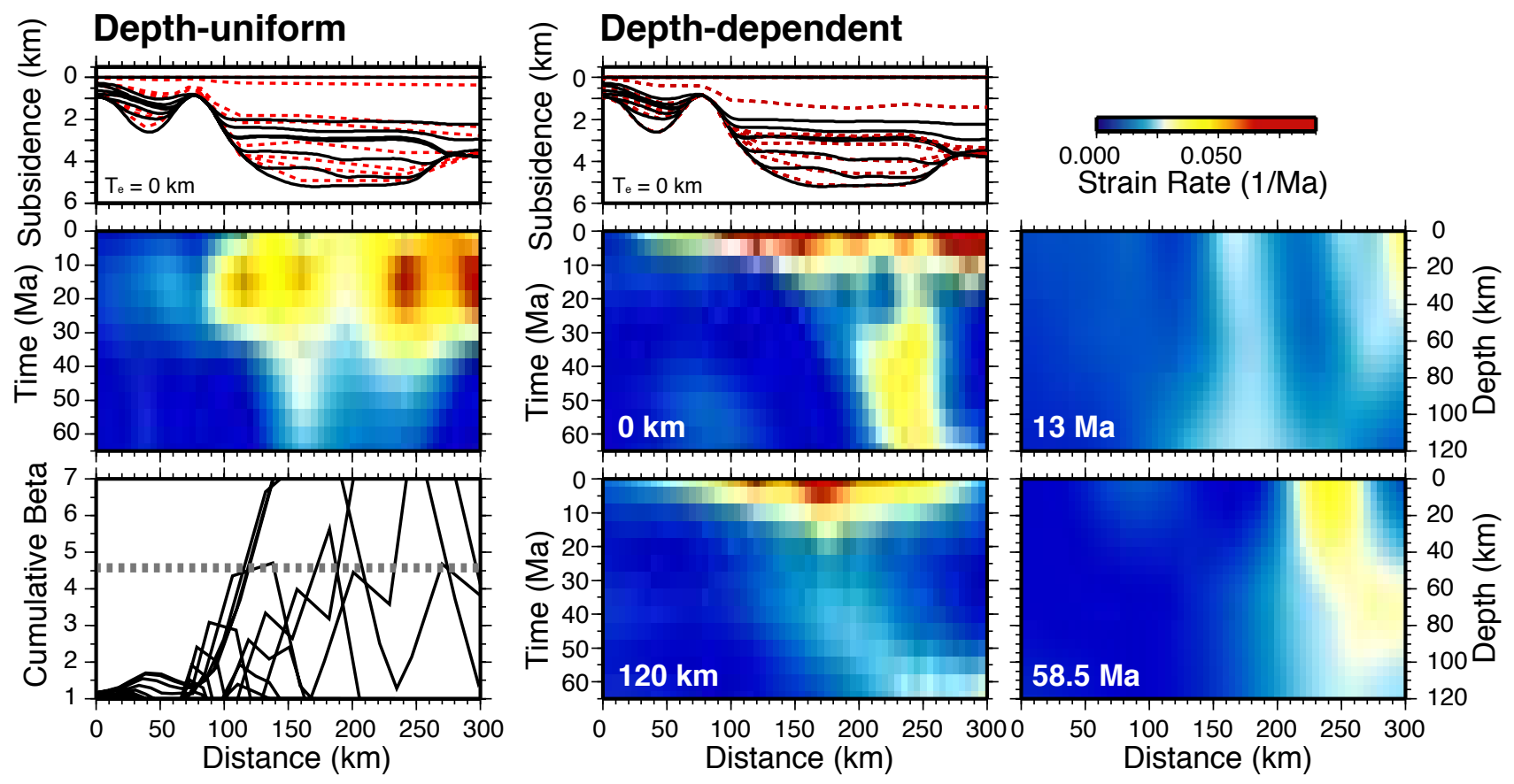
Figure 7, Shillington et al.

\section{a. Case 1}
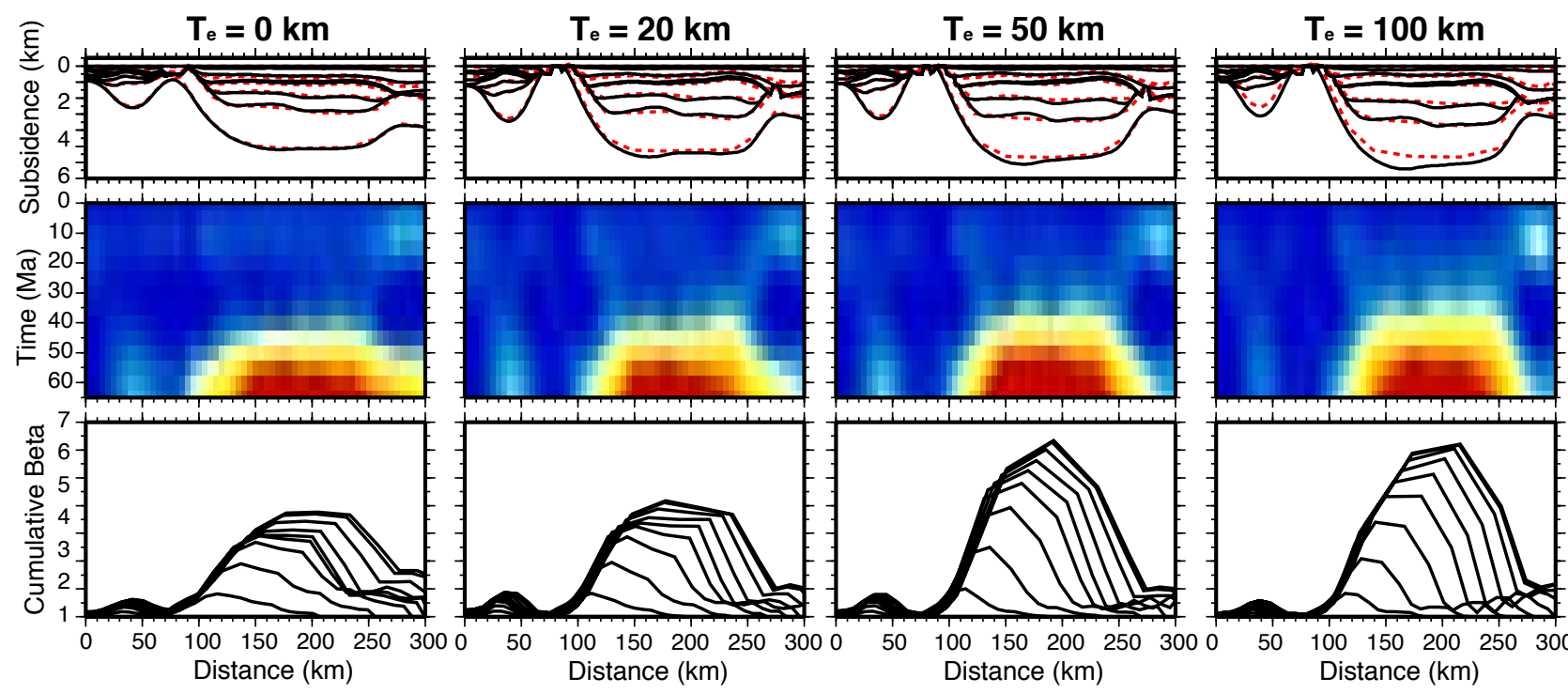

b. Case 2
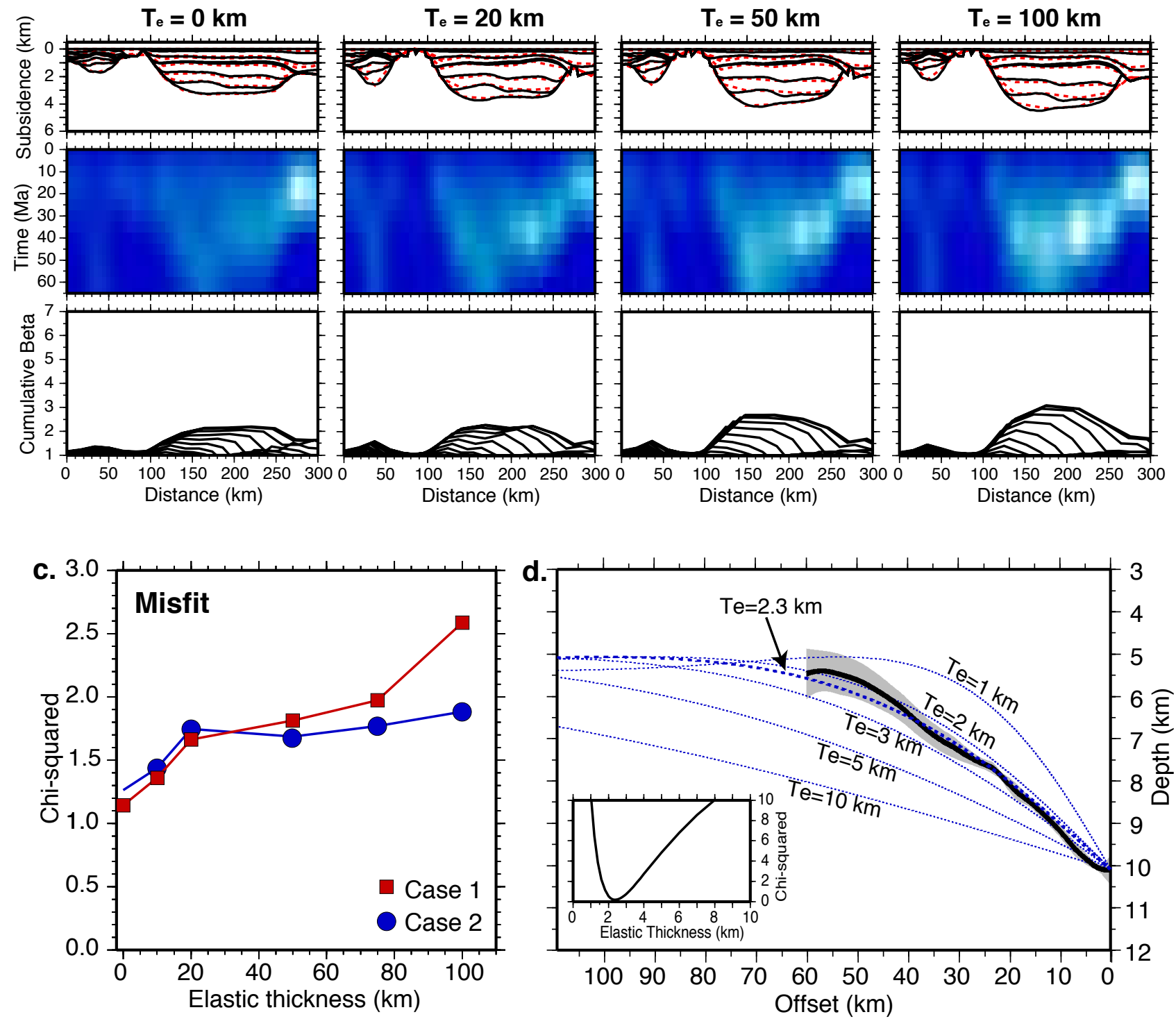
Figure 8, Shillington et al.

a.

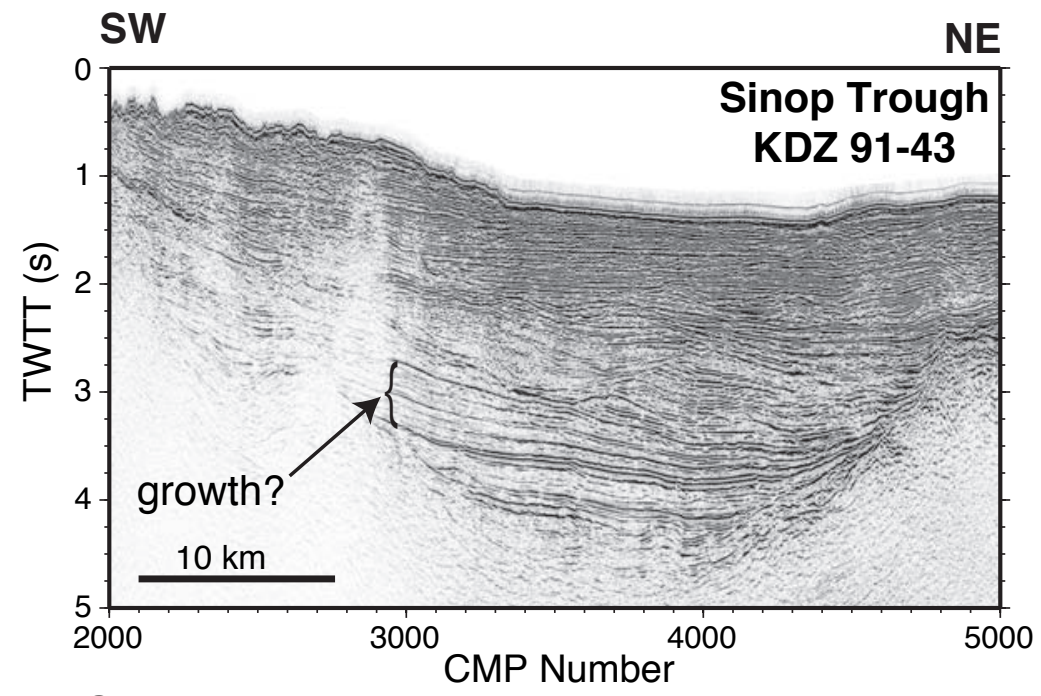

bW NE

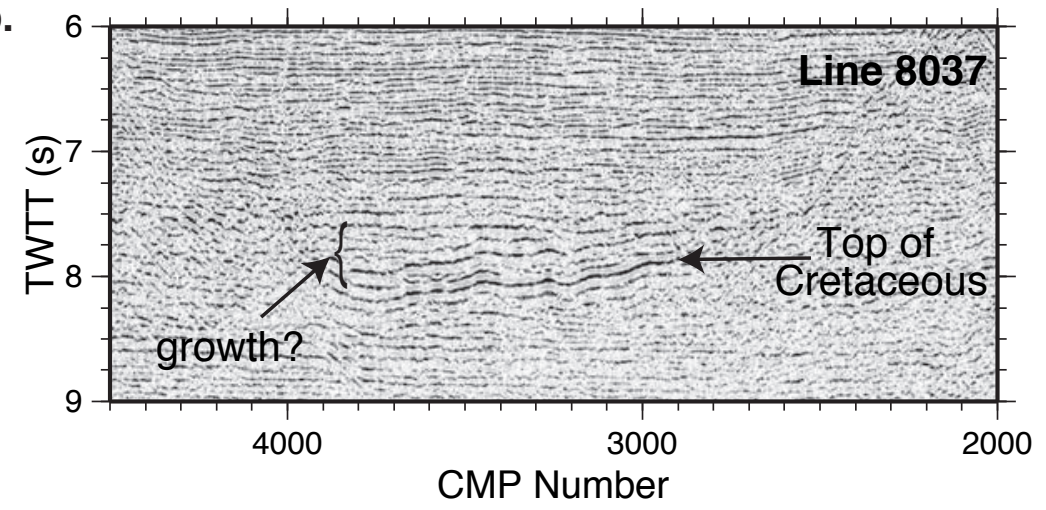


Figure 9, Shillington et al.

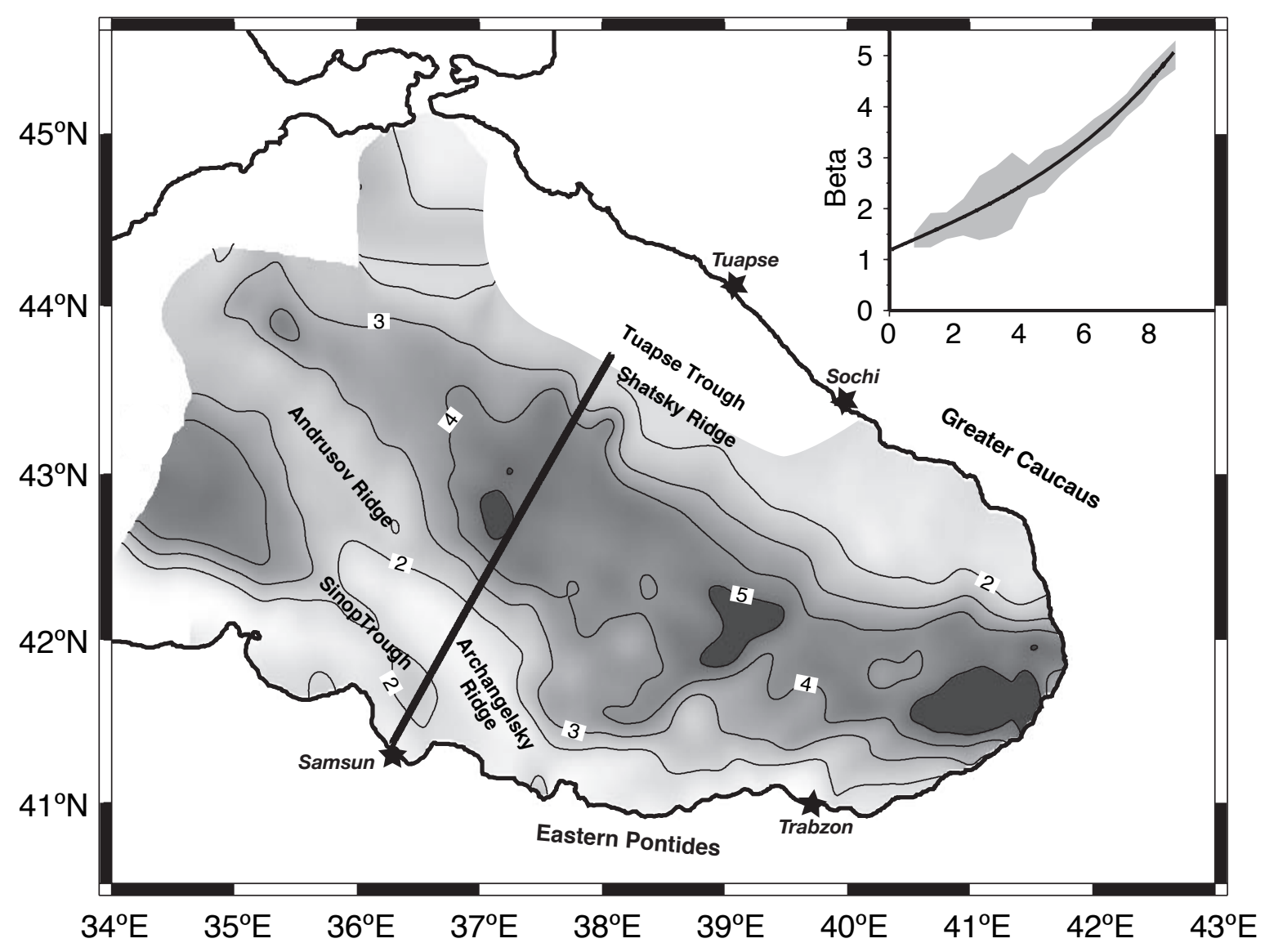

